\title{
Article
}

\section{An Anthropological Approach to Modern Forfeiture Law: The Symbolic Function of Legal Actions Against Objects}

\section{Paul Schiff Berman*}

In 1996 the Supreme Court issued two opinions, Bennis $v$. Michigan $^{1}$ and United States v. Ursery, ${ }^{2}$ emphasizing the constitutionality of civil forfeiture schemes under both the Due Process and Double Jeopardy Clauses of the Fifth Amendment.

* Associate Professor, University of Connecticut School of Law. I wish to thank Laura Dickinson, Bill Nelson, John Owens, and Silvija Strikis for helpful comments on earlier drafts of this Article. I note that, although I served as law clerk to Associate Justice Ruth Bader Ginsburg of the United States Supreme Court during the 1997 Term, I was not working at the Court when the two cases discussed in this Article-Bennis v. Michigan, 516 U.S. 442 (1996), and United States v. Ursery, 518 U.S. 267 (1996) - were decided, and I have not discussed the rationale behind these decisions with Justice Ginsburg. Thus, the analysis in this Article should not in any way be construed as an "inside" account.

1. 516 U.S. 442 (1996).

2. 518 U.S. 267 (1996). 
These decisions, and civil forfeiture schemes generally, have faced strong criticism from scholars and civil libertarians. Critics point out that law enforcement agencies "perpetrate astonishing outrages on owners of private property through forfeitures,"3 and they argue that civil forfeiture runs afoul of any number of constitutionally-based guarantees, from the Fourth Amendment's warrant requirement ${ }^{4}$ to the Eighth Amendment's concept of proportional punishment. ${ }^{5}$

Among the arguments advanced against civil forfeiture has been one based on its origins. The so-called "legal fiction" underlying forfeiture is that the government is acting against the property itself, rather than against the owner. Commentators have traced this fiction to the Middle Ages. Under the law of the deodand, an inanimate object that caused a death was deemed to be "guilty" of a crime and therefore was offered to God through forfeiture to the King. Those opposed to today's forfeiture laws have seized upon this history to demonstrate the supposedly senseless origins of forfeiture. "Implicit in this discussion is the absurdity of perpetuating a system that attributed evil to an ox, a tree, a boat, and a broadsword."

The Supreme Court also has invoked the history of civil forfeiture, but for a different purpose. Although the Court has sometimes acknowledged that the fiction underlying civil forfeiture may seem unfair, it has nevertheless upheld forfeiture schemes based on the historical prevalence and acceptance of the practice. For example, in one of this century's early forfeiture cases, the Court concluded that, "whether the reason for [the challenged forfeiture scheme] be artificial or real, it is too firmly fixed in the punitive and remedial jurisprudence of the country to be now replaced." In a later case, the Court also upheld a forfeiture, explicitly referring to the law of the deodand. ${ }^{8}$ And in both Bennis and Ursery, the Court cited "a long and unbroken line of cases," dating back to "the earliest years of this Nation," 10 to support its conclusions. This unbroken line of cases,

3. LeONARD W. LeVY, A LICENSE TO STEAL: The ForfeituRE OF PROPERTY 1 (1996).

4. See, e.g., Amy D. Ronner, Prometheus Unbound: Accepting a Mythless Concept of Civil In Rem Forfeiture with Double Jeopardy Protection, 44 BUFF. L. REv. 655, $673-74$ (1996) (discussing the "downright oppressive" nature of 21 U.S.C. $\S 881$ (one of the federal forfeiture statutes), and noting that warrantless searches are permitted under the statute and its attendant rules and procedures).

5. See, e.g., Catherine Cerna, Economic Theory Applied to Civil Forfeiture: Efficiency and Deterrence Through Reallocation of External Costs, 46 HASTINGS L.J. 1939, 1940 (1995) (arguing the disproportionality, for example, of the 1991 forfeiture of a home where police discovered 354 marijuana plants, grown for the owner's private use and having a market value of only $\$ 137.50$ ).

6. Leslie A. Hakala, Book Note, Opposing Forfeiture, 106 Y ALE L.J. 1319, 1320 (1997).

7. J.W. Goldsmith, Jr.-Grant Co. v. United States, 254 U.S. 505, 511 (1921).

8. See Calero-Toledo v. Pearson Yacht Leasing, 416 U.S. 663, 680-82 (1974).

9. Bennis, 516 U.S. at 446 .

10. Ursery, 518 U.S. at 274. 
by most accounts, derived its forfeiture rules from the English common law of the deodand. ${ }^{11}$

Although both the critics and the Court have used the history of forfeiture actions to support their conclusions, neither side has made any serious attempt to understand this history. By attacking forfeiture practice in the Middle Ages as an archaic and nonsensical custom, critics make no effort to see the law of the deodand within its cultural context. And by simply invoking historical precedent as a talismanic answer to today's judicial riddles, the Court fails to provide any analysis of how that precedent might be justified. ${ }^{12}$

This Article seeks to offer a more nuanced view of this history. The evidence suggests that, throughout the medieval period, legal actions against both inanimate objects and animals were widespread. Indeed, it appears that the origin of such trials extends as far back as ancient Greece. Although it would be impossible to discover with any certainty the reasons for this seemingly irrational practice, by examining it more closely, we may see that these legal actions

11. See, e.g., United States v. Bajakajian, 118 S. Ct. 2028, 2034 n.5 (1998); Austin v. United States, 509 U.S. 602, 611-18 (1993); Calero-Toledo, 416 U.S. at 680-83; United States v. United States Coin \& Currency, 401 U.S. 715, 720 (1971); Oliver W. Holmes, ThE COMMON LAW 23-33 (Mark D. Howe ed., Harvard Univ. Press 1963) (1881); Jimmy Gurule, Introduction: The Ancient Roots of Modern Forfeiture Law, 21 J. LEGIS. 155, 156 (1995) ("The conceptual underpinnings of civil forfeiture can be traced back to English common law."). Several authors have argued that modern forfeiture law actually arises from admiralty and not deodands. See Grant Gilmore \& Charles Black, The LAW of AdMIRALTY 484 (1957); Donald J. Boudreaux \& A.C. Pritchard, Innocence Lost: Bennis v. Michigan and the Forfeiture Tradition, 61 Mo. L. REV. 593, 601-02; James R. Maxeiner, Bane of American Forfeiture Law-Banished at Last?, 62 CORNELL L. REV. 768, 771 (1977). However, given that the law of deodands did exist in the American colonies, see infra text accompanying notes 177-81, and given that both deodands and admiralty law conceptualize the object as a guilty party subject to seizure, it is difficult to determine with any certainty which tradition gave rise to modern forfeiture practice. Moreover, because the two traditions use the same "guilty property" narrative, the distinction makes little difference for the purpose of this Article.

12. Unfortunately, the decisions in Bennis and Ursery are not at all anomalous in this regard. "The case reporters are replete with ... decisions upholding the constitutionality of civil forfeiture statutes based merely on the recognition that they have always been permitted in the past." Robert Lieske, Civil Forfeiture Law: Replacing the Common Law with a Common Sense Application of the Excessive Fines Clause of the Eighth Amendment, 21 WM. MITCHELL L. REv. 265, 267 (1995). See, e.g., Calero-Toledo, 416 U.S. at 680 (finding the civil forfeiture at issue constitutional because "[t]he historical background of forfeiture statutes in this country and this Court's prior decisions sustaining their constitutionality lead to that conclusion"); Canadian Aviator, Ltd. v. United States, 324 U.S. 215, 224 (1945) ("Such personification of the vessel, treating it as a juristic person whose acts and omissions, although brought about by her personnel, are personal acts of the ship for which, as a juristic person, she is legally responsible, has long been recognized by this Court."); Van Oster v. Kansas, 272 U.S. 465, 468 (1926) ("It has long been settled that statutory forfeiture[] of property ... is not a violation of the Due Process Clause of the Fifth Amendment."); J.W. Goldsmith, Jr.-Grant Co. v. United States, 254 U.S. 505, 511 (1921) (stating that civil forfeitures are "too firmly fixed in the punitive and remedial jurisprudence of this country to now be displaced"); United States v. Campos, 859 F.2d 1233, 1240 (6th Cir. 1988) ("After analysis of the historical background and development of the law of forfeiture, innocence of the owner of property was rejected as a defense to forfeiture despite the hardship involved."); Associates Investment Co. v. United States, 220 F.2d 885, 888 (5th Cir. 1955) ("[I]t is well settled that [forfeiture] is not a denial of due process of law, or a taking of property for public use without fair compensation."). 
performed social functions for the community that are not necessarily so different from the function of modern forfeiture law. Thus, it is a mistake to dismiss the practice of trying inanimate objects or animals as the unenlightened custom of a bygone era. ${ }^{13}$ Rather, by drawing on scholarship in anthropology and literary criticism, I argue that such legal proceedings permitted the community to heal itself after the breach of a social norm by creating a narrative ${ }^{14}$ whereby a symbolic transgressor of the established

13. See Nicholas Humphrey, Foreword to E.P. Evans, The CRIMINAL Prosecution AND Capital Punishment of Animals at xix (Faber \& Faber 1988) (1906):

We must be wary of ... assuming that people of mediaeval Europe were so different from ourselves that it is not worth applying any of the standards of rationality we have today.... [T] o suggest, for example, that the grown-up people involved really could not tell the difference between animals and human beings, cannot be right. Other people may be other, but they are not necessarily stupid.

There can be no doubt that medieval society was fundamentally different from our own and that people in medieval times may have had a fundamentally different view of the world, the community, and the individual. See generally JOHAN HUIZINGA, THE WANING OF THE MIDDLE AGES (1954). These differences may account for some of the seemingly eccentric legal customs of that era. Nevertheless, particularly because our modern law of forfeiture derives from this period, it makes little sense simply to dismiss the ancient practice out of hand. Rather, an attempt to understand the cultural roles these proceedings may have performed permits us to question seriously whether such roles are still vestigially present in our own customs.

14. I use the word narrative in a broad sense to describe any type of explanatory framework for describing reality. Over the past several decades, anthropologists, literary critics, and legal scholars have increasingly studied the role of narratives in structuring our experience of the world. See, e.g., THE ANTHROPOLOGY OF EXPERIENCE (Victor W. Turner \& Edward M. Bruner eds., 1986) (collecting essays exploring the relationship between experience and narratives used to describe experience); ROLAND BARTHES, Introduction to the Structural Analysis of Narratives, in IMAGE-MUSIC-TEXT 79 (Stephen Heath trans., 1977) (using linguistics to construct, describe, and classify a theory of narratives); VINCENT CRAPANZANO, TUHAMI: PORTRAIT OF A MOROCCAN (1980) (exploring conflicting storytelling styles between anthropologist and subject); JACOUES DERRIDA, OF GRAMMATOLOGY (Gayatri C. Spivak trans., 1974) (drawing on the work of linguist Ferdinand de Saussure to argue that language provides no direct access to reality and therefore what we call "reality" is really a set of narrative conventions); CLAUDE LEVI-STRAUSS, The Effectiveness of Symbols, in STRUCTURAL ANTHROPOLOGY 186 (Claire Jacobson \& Brooke G. Schoepf trans., 1963) (describing the use of narratives to encapsulate pain); RENATO ROSALDO, CULTURE AND Truth: The Remaking of Social ANAlysis (1989) (advocating that social science acknowledge the role of conflicting narratives and subjectivity in descriptions of reality); Peter Brooks, The Law as Narrative and Rhetoric, in LAW'S STORIES 14, 14 (Peter Brooks \& Paul Gewirtz eds., 1996) ("Narrative appears to be one of our large, all-pervasive ways of organizing and speaking the world-the way we make sense of meanings that unfold in and through time."); Robert M. Cover, Nomos and Narrative, 97 HARv. L. REV. 4, 4 (1983) (arguing that "[n]o set of legal institutions or prescriptions exists apart from the narratives that locate it and give it meaning"); Hayden White, The Value of Narrativity in the Representation of Reality, in ON NARRATIVE 1, 2 (W.J.T. Mitchell ed., 1981) (finding that "[n]arrative is a metacode, a human universal on the basis of which transcultural messages about the nature of a shared reality can be transmitted"). Narratives are now seen as encompassing almost any form of social discourse and not just traditional narrative forms, such as folktales. See, e.g., BARTHES, supra, at 79:

The narratives of the world are numberless. Narrative is first and foremost a prodigious variety of genres. ... [U]nder this almost infinite diversity of forms, narrative is present in every age, in every place, in every society; it begins with the very history of mankind and there nowhere is nor has been a people without narrative.

The focus on narratives allows critics to study how the vessel by which we impart social 
order was deemed to be "guilty" of a "crime" and cast beyond the boundaries of the society. I then suggest that at least some aspects of modern civil forfeiture law may fulfill a similar function. Indeed, the importance of this symbolic aspect of civil forfeiture may provide a way of thinking about the Supreme Court's recent jurisprudence in this area.

My analysis proceeds in three parts. Part I summarizes the Court's decisions in Bennis and Ursery and surveys some of the criticisms of those decisions and of modern forfeiture law generally. This discussion reveals that, despite the references to history, neither side in the forfeiture debate has attempted seriously to understand the practice of taking legal action against non-human perpetrators or to explore how that practice might still be relevant today. Part II traces the history of such legal actions from antiquity to medieval and early modern England and Europe, and suggests that these legal proceedings created a societal ritual ${ }^{15}$ for removing a transgressor from the community to expiate a wrong. Significantly, for the purpose of these actions, it appears to have been irrelevant whether or not the owner of the offending object was guilty. Indeed, the actions against objects were considered completely separate from any civil or criminal actions that might be taken against the owner. Finally, Part III attempts to link these historical proceedings with modern forfeiture law. Still today, a forfeiture proceeding can serve to remove an offensive symbol of wrongdoing from the community, thereby fulfilling a social function that is quite different from the desire to punish the culpable individual who may have used the object in question.

Certainly our society may continue to seize objects for a variety of reasons distinct from the symbolic function I discuss. For example, it has often been argued (both historically and in modern times) that

knowledge - conversational forms, gestures, news items - itself constitutes our apprehension of reality.

15. The term "ritual" will be used throughout this Article to mean a formal, socially standardized, and repetitive action wrapped in a web of symbolism that serves to channel emotion, define experience, and guide understanding. See DAVID I. KERTZER, RITUAL, POLITICS AND POWER 8 (1988). This relatively broad definition follows the conceptual understanding employed by most contemporary anthropologists. Until a generation ago, the term "ritual" was more often used only to describe supernatural or religious rites. That earlier definition stemmed from Emile Durkheim's influential statement that rituals are "rules of conduct which prescribe how a man should comport himself in the presence of ... sacred objects." EMile Durkheim, The ElEMENTARY ForMS OF Religious LifE 56 (Joseph W. Swain trans., 1915). Durkheim believed that rituals were coercive moral forces dictating acceptable behavior and, as such, identified rituals with organized religion. Contemporary cultural scholars have broadened the focus somewhat by studying how all members in a culture use the narratives produced by various social institutions to construct meaning. Thus, ritual has become "an analytical category that helps us deal with the chaos of human experience and put it into a coherent framework." KERTZER, supra, at 8; see also id. at 1-14 (examining interplay of politics, symbolism, and ritual). 
the longevity of forfeiture practice is explainable in part because those with legal authority derive economic benefit from seizing property. ${ }^{16}$ This Article makes no attempt to rebut these contentions, for I am not here concerned with trying to explain why forfeitures or trials of animals and inanimate objects have occurred. Nor do I take a normative position on either the wisdom or the constitutionality of civil forfeiture. Rather, I argue that we cannot debate the efficacy of forfeiture without first recognizing all the possible functions forfeiture might fulfill for a community. ${ }^{17}$ And the symbolic aspect of forfeiture provides one possible way of understanding the practice that appears to have been overlooked. In addition, focusing on this symbolic function may shed useful light on the Court's evocation of history in Bennis and Ursery.

In the end, by understanding a custom seemingly so unenlightened, we may come to understand our own need for symbolic rituals to cleanse a community after a wrong has been done. ${ }^{18}$ Only then can a debate about the uses and abuses of civil forfeiture truly begin.

16. See, e.g., Philippe de Beaumanolr, Coutumes de Beauvaisis $\S 1944$ (A.M. Salmon ed., A. Picard 1970) (1283) (suggesting that the animal trials served only as a profitable source of income for the feudal lords); HENRY HYDE, FORFEITING OUR PROPERTY RIGHTS 30 (1995) ("[L]aw enforcement officials are allowed to keep all the proceeds from the property they confiscate, an invitation to uncontrollable abuse.").

17. It is important to recognize the difference between exploring the possible social functions of a practice and explaining why that practice exists. Critics have often attacked functionalist arguments for implying an unproved causal link. See, e.g., JON ELSTER, ULYSSES AND THE SIRENS: STUDIES IN RATIONALITY AND IRRATIONALITY 32 (1979) ("A large body of sociological literature seems to rest upon an implicit regulative idea that if you can demonstrate that a given pattern has unintended, unrecognized and beneficial effects, then you have explained why it exists and persists."). However, this Article does not explore the possible social functions of legal proceedings against non-human transgressors for the purpose of showing why these proceedings took place. Rather, a discussion of social function is useful in order to recognize the cultural roles such proceedings may fulfill.

18. Professor John Langbein likewise has used historical European and English judicial practices to illuminate contemporary American legal procedures regarding plea bargaining, see John H. Langbein, Torture and Plea Bargaining, 46 U. CHI. L. REV. 3 (1978), the rules of evidence, see John H. Langbein, Historical Foundations of the Law of Evidence: $A$ View from the Ryder Sources, 96 COLUM. L. REV. 1168 (1996); John H. Langbein, The Historical Origins of the Privilege Against Self-Incrimination at Common Law, 92 MICH. L. REV. 1047 (1994), and the role of lawyers, see John H. Langbein, The Criminal Trial Before the Lawyers, $45 \mathrm{U}$. CHI. L. REV. 263 (1978). Although Langbein does not necessarily approve of the contemporary legal procedures that have developed from these historical sources, see, e.g., John H. Langbein, Cultural Chauvinism in Comparative Law, 5 CARDOzo J. INT'L \& COMP. L. 41, 41 (1997) (describing the "disgraceful, truth-defeating excesses of adversary civil procedure in the United States"), his work clearly reflects the understanding that studying the historical origins of contemporary doctrines is important. See also BARBARA J. SHAPIRO, "BEYOND REASONABLE DoubT" aNd "Probable CAUSE": Historical PERSPECTIVES ON THE ANGLO-AMERICAN LAW OF EVIDENCE (1991) (tracing historical development of contemporary evidentiary rules). 


\section{BENNIS, URSERY, AND THE CRITICS OF MODERN FORFEITURE LAW}

This Part summarizes the Supreme Court's recent pronouncements on civil forfeiture, Bennis v. Michigan ${ }^{19}$ and United States v. Ursery. ${ }^{20}$ Although the opinions for the Court in both cases simply recite historical precedents undergirding civil forfeiture without much analysis, both cases endorse concepts that, as we will see, are rooted in the historical understanding of forfeiture as a symbolic cleansing of an object that has transgressed societal norms. Bennis adopts the idea that the culpability of the object's owner is irrelevant because the object itself is deemed to be guilty. And Ursery endorses the notion that forfeiture is a remedial action brought against the object to make the community whole and is therefore distinct from criminal sanctions that may be pursued against the owner.

\section{A. Bennis v. Michigan: The Object Is Guilty Even if the Owner Is Not}

The Bennis case began in the fall of 1988 along Eight Mile Road in Detroit, where prostitutes were enjoying "a flourishing business."21 In response to demands from residents of the area "for relief from the blighting effect of a disagreeable vice market,"22 Wayne County prosecutors revived a Prohibition-era statute that had been used against smugglers importing liquor from Canada. ${ }^{23}$ This law permitted prosecutors to declare certain property used in criminal activity a "public nuisance" and to confiscate it. ${ }^{24}$

Subsequently, the Wayne County police spotted John Bennis engaged in an illicit act with a prostitute in the 1977 Pontiac that he and his wife Tina jointly owned. ${ }^{25}$ John Bennis was charged with "gross indecency," for which he subsequently was convicted and fined. ${ }^{26}$ The State of Michigan then went further and attempted to seize the automobile under the public nuisance law.

At the nuisance proceeding in the trial court, Tina Bennis testified - without contradiction - that she had no knowledge of her

\footnotetext{
19. 516 U.S. 442 (1996).

20. 518 U.S. 267 (1996).

21. David G. Savage, Innocence Punished, A.B.A. J., May 1996, at 47, 47.

22. George E. Ward, Letter to the Editor, Seizure Law Constitutionally Solid, DET. NEwS, Mar. 20, 1996, available in LEXIS, Nexis Library, Arcnws File.

23. See Savage, supra note 21 , at 47.

24. MICH. COMP. LAwS ANN. $\$ 600.3801$ (West Supp. 1996) ("Any building, vehicle, boat, aircraft, or place used for the purpose of lewdness, assignation or prostitution or gambling, or used by, or kept for the use of prostitutes or other disorderly persons,... is declared a nuisance, ... and all ... nuisances shall be enjoined and abated as provided in this act and as provided in the court rules.").

25. See Michigan v. Bennis, 527 N.W.2d 483, 486 (Mich. 1994).

26. See id.
} 
husband's use of the car for illicit acts. ${ }^{27}$ The Michigan Supreme Court nonetheless upheld the forfeiture, concluding that Tina Bennis's claim of innocence was "without constitutional consequence" under the Due Process Clause of the Fourteenth Amendment. ${ }^{28}$ After surveying the forfeiture jurisprudence of the United States Supreme Court, the Michigan court concluded that "[h]istorically, consideration was not given to the innocence of an owner because the property subject to forfeiture was the evil sought to be remedied." 29

The United States Supreme Court affirmed, with Chief Justice William Rehnquist writing for the five-to-four majority. The opinion for the Court is notable in part because, except for one paragraph that refers to the general deterrent value of forfeiture proceedings, ${ }^{30}$ it never discusess any possible rationale supporting the Court's decision to uphold a forfeiture against an innocent owner. Rather, the Court simply recites what it calls "a long and unbroken line of cases" permitting such an action. ${ }^{31}$ Moreover, none of the passages quoted from this line of cases provides a rationale either. Thus, it appears from the decision that civil forfeiture against an innocent owner rests only on the invocation of precedent, without any historical analysis or explanation.

Chief Justice Rehnquist's survey of Supreme Court precedent begins with The Palmyra ${ }^{32}$ in 1827. In that case, the Court rejected a shipowner's contention that his vessel could not be forfeited for privateering unless he was convicted of the charge. Instead, the Court determined that " $t]$ he thing is here primarily considered the offender, or rather the offence is attached primarily to the thing."

Similarly, in Harmony v. United States, ${ }^{34}$ an 1844 decision, Justice Story wrote for the Court that "[t]he vessel which commits the aggression is treated as the offender, as the guilty instrument or thing to which the forfeiture attaches, without any reference whatsoever to the character or conduct of the owner." 35 The decision also quotes Chief Justice Marshall in another admiralty case:

This is not a proceeding against the owner; it is a proceeding against the vessel for an offence committed by the vessel; which

27. See Joint Appendix at 9, Bennis v. Michigan, 516 U.S. 442 (1996) (No. 94-8729).

28. Michigan v. Bennis, 527 N.W.2d at 494.

29. Id. at 493-94.

30. See Bennis, 516 U.S. at 452.

31. Id. at 446.

32. 25 U.S. (12 Wheat.) 1 (1827).

33. Id. at 14.

34. 43 U.S. (2 How.) 210 (1844).

35. Id. at 233 . 
is not the less an offence, and does not the less subject her to forfeiture because it was committed without the authority and against the will of the owner. ${ }^{36}$

The Court's opinion in Bennis continues with an 1877 case, Dobbins's Distillery $v$. United States, ${ }^{37}$ which involved the forfeiture of a distillery because the lessee of the property had failed to pay federal taxes. Although the purportedly innocent owner objected to the forfeiture, the Dobbins's Distillery Court noted that "[t]hroughout the trial, the claimant appears to have assumed, as the theory of the defence to the information, that he was the accused party, and that he was on trial for a criminal offence created and defined by an Act of Congress. ${ }^{38}$ However, according to the Court, "the forfeiture claimed in the information is aimed against the distillery," 39 and "[n]othing can be plainer in legal decision than the proposition that the offence therein defined is attached primarily to the distillery, and the real and personal property used in connection with the same, without any regard whatsoever to the personal misconduct or responsibility of the owner ...." Indeed, the decision in Dobbins's Distillery quotes the earlier language in The Palmyra and Harmony to support its understanding of forfeiture proceedings. ${ }^{41}$

Turning to twentieth-century cases, the Bennis Court cites a 1921 decision, J.W. Goldsmith, Jr.-Grant Co. v. United States. ${ }^{42}$ In that case, the Court acknowledged that seizing the property of an innocent owner "seems to violate that justice which should be the foundation of the due process of law required by the Constitution" and indicated that, "[i]f the case were the first of its kind, it and its apparent paradoxes might compel a lengthy discussion to harmonize [the forfeiture] with the accepted tests of human conduct." ${ }^{13}$ Nevertheless, relying on Dobbins's Distillery and the cases cited therein, the Court concluded that forfeiture was "too firmly rooted in the punitive and remedial jurisprudence of the country to be now displaced." ${ }^{44}$

Goldsmith-Grant is also the first of this line of cases to refer explicitly to the older English actions against inanimate objects. The

36. Id. at 234 (quoting United States v. The Schooner Little Charles, 26 F. Cas. 979, 982 (D. Va. 1818) (No. 15,612)).

37. 96 U.S. (6 Otto) 395 (1877).

38. Id. at 399 .

39. Id.

40. Id. at 401.

41. See id at 399-400.

42. 254 U.S. 505 (1921).

43. Id. at $\mathbf{5 1 0 .}$

44. Id. at 511 . 
Court observed that there "is some analogy" between the forfeiture scheme at issue and "the law of deodand by which a personal chattel that was the immediate cause of the death of any reasonable creature was forfeited." ${ }^{45}$ As to a possible rationale underlying deodands, the Court referred to a "superstitious reason" for the law ${ }^{46}$ but did not elaborate, preferring instead to quote Blackstone's theory "“[t]hat such misfortunes are in part owing to the negligence of the owner, and therefore, he is properly punishable by such forfeiture." ${ }^{47}$ Thus, the more "superstitious" reasons that might be embedded in the history of deodands were left unexplored. ${ }^{48}$

Although the subsequent decision in Van Oster v. Kansas ${ }^{49}$ did little more than invoke Dobbins's Distillery and Goldsmith-Grant to justify upholding a forfeiture against a purportedly innocent owner, the 1974 opinion for the Court in Calero-Toledo v. Pearson Yacht Leasing $^{50}$ (the final case in this line cited in the Bennis decision) again pointed to the link between deodands and forfeiture actions. The Court even went so far as to observe that "[t]he origins of the deodand are traceable to Biblical and pre-Judeo-Christian practices, which reflected the view that the instrument of death was accused and that religious expiation was required." ${ }^{.51}$ Ultimately, however, the decision only invokes this historical precedent and never actually explores the quasi-religious justifications for deodands or how these justifications might still be relevant.

Having discussed the foregoing cases, the decision for the Court in Bennis concludes, as did the Court in Goldsmith-Grant, that the historical practice of forfeiture itself justifies its continuation. Indeed, it is quite striking that Chief Justice Rehnquist not only fails to mention possible religious or symbolic justifications for civil forfeiture but also appears to find it unnecessary to provide any justification at all for forfeiture practice beyond adherence to precedent. The opinion of the Court devotes only one paragraph, near the end of the decision, to a discussion of forfeiture's justifications, concluding rather half-heartedly that forfeitures, even

45. Id. at 510 .

46. $I d$. at 511 .

47. Id. (quoting 1 WILLIAM BLACKSTONE, COMMENTARIES *301 (alteration added)).

48. The Court did quote from Blackstone's observation linking the law of deodand to proceedings against animals and inanimate objects under Mosaic and Athenian law. See id.; see also infra text accompanying notes 144-46. However, despite the fact that these proceedings seemed to have little to do with a conception of negligence, see infra text accompanying notes 198-205, the Court did not challenge Blackstone's explanation for deodands, nor did it embark on its own historical analysis.

49. 272 U.S. 465 (1926).

50. 416 U.S. 663 (1974).

51. Id. at 681 (citing OlIVER W. HOLMES, THE COMMON LAW (1881)). 
from innocent owners, can serve a deterrent purpose. ${ }^{52}$

Justice Clarence Thomas wrote a separate concurrence, acknowledging the seeming unfairness of the forfeiture as applied to Tina Bennis, but relying, like the Chief Justice, on historical practice: "One unaware of the history of forfeiture laws and 200 years of this Court's precedent regarding such laws," he wrote, "might well assume that such a scheme is lawless - a violation of due process." Justice Thomas, however, approved the practice of depriving potentially innocent owners of their property because tradition sanctified such practice: "As detailed in the Court's opinion and the cases cited therein, forfeiture of property without proof of the owner's wrongdoing... has been permitted in England and this country, both before and after the adoption of the Fifth and Fourteenth Amendments." ${ }^{\circ 4}$ Justice Thomas cited the Court's plurality in Burnham v. Superior Court ${ }^{55}$ for the proposition that a process of law traceable to settled usage in England and this country must be considered to comport with due process of law. ${ }^{56}$

To the surprise of some commentators, Justice Ruth Bader Ginsburg joined the majority in affirming the forfeiture ${ }^{57}$ Her brief concurrence will be discussed in more detail below. For now it will suffice to note that, although her opinion does not explicitly refer to the history of forfeiture practices at all, it does appear to invoke the idea that forfeiture may have a symbolic function, an idea that can perhaps best be understood by analyzing the history of legal proceedings against inanimate objects and animals.

In dissent, Justice John Paul Stevens called the notion of finding objects guilty a "hoary fiction" 58 and noted that the seizure of the car could not be justified under any of what he considered to be the plausible rationales for forfeiture. Thus, for example, he observed that the car was not contraband, which might render seizure necessary to remove it from circulation. ${ }^{59}$ It was not stolen property that must be returned to the owner as restitution. ${ }^{60}$ It was not property about which "the law may reasonably presume that the owner... is aware of the principal use being made of that

\footnotetext{
52. See Bennis, 516 U.S. at 452.

53. Id. at 454 (Thomas, J., concurring).

54. Id.

55. 495 U.S. 604,619 (1990) (plurality opinion).

56. See Bennis, 516 U.S. at 454-55 (Thomas, J., concurring).

57. See, e.g., Savage, supra note 21 , at 48 ("Ginsburg's opinion in Bennis ran counter to both expectations from oral arguments and her larger reputation in some quarters for liberalism on the bench."); see also infra notes 262-63 and accompanying text.

58. Bennis, 516 U.S. at 466 (Stevens, J., dissenting).

59. See id. at 459.

60. See id. $459-60$.
} 
property. "61 It was not property that actually facilitated the offense because the act of prostitution could have occurred in numerous locations. ${ }^{62}$ And, the removal of the car would not prevent repeated violations of the law. ${ }^{63}$

Justice Stevens does acknowledge in a footnote, however, that there might be another possible rationale underlying the forfeiture, namely "that the neighborhood where the offense occurred exhibited an ongoing 'nuisance condition' because it had a reputation for illicit activity, and the car contributed to that "condition." "64 However, he dismisses this theory as "tenuous." According to Justice Stevens, "any other stationary part of the neighborhood where such an offense could take place-a shed, for example, or an apartment-could be forfeited on the same rationale," and he therefore rejects the idea. ${ }^{66}$ Nevertheless, a review of the history underlying forfeiture indicates that perhaps this rationale should not be dismissed quite so easily. ${ }^{67}$

\section{B. United States v. Ursery: The Difference Between Forfeiture and Punishment}

The Supreme Court's decision in Ursery concerned whether forfeiture should be deemed to be "punishment" such that a forfeiture action accompanying a criminal proceeding violates the Double Jeopardy Clause of the Fifth Amendment. As in Bennis, the Chief Justice, writing for the Court, cites historical precedent dating to "the earliest years of this Nation"68 as well as "at common law" support his view that forfeiture is not "punishment." And, as in Bennis, there is little explanation of any rationale underlying the forfeiture/punishment distinction.

Ursery was a consolidation of two different cases. In the first, Michigan police found marijuana growing adjacent to Guy Ursery's house and discovered marijuana seeds, stems, stalks, and a growlight within the house. The United States instituted civil forfeiture

\footnotetext{
61. Id. at 461 .

62. See id. at $462-63$.

63. See id. at 465 .

64. Id. at 464 n.9 (quoting Michigan v. Bennis, 527 N.W.2d 483, 491 (Mich. 1994)).

65. Id.

66. Id.

67. Justice Kennedy also wrote a brief dissenting opinion in Bennis, in which he asserted that the practical realities of needing to seize ships to insure compensation for injuries even though the vessels' owners were not present "provided a better justification for forfeiture than earlier, more mechanistic rationales," such as deodands, but that those "practical" reasons for forfeiture should not be extended to automobiles. See id. at 472-73 (Kennedy, J., dissenting).

68. Ursery, 518 U.S. at 274.

69. Id. at 275 .
} 
proceedings against the house because it had been used to facilitate the unlawful processing and distribution of a controlled substance. Ursery ultimately agreed to pay the government $\$ 13,250$. Shortly before this settlement, Ursery was indicted for manufacturing marijuana. After being found guilty, Ursery was sentenced to over six years in prison. ${ }^{70}$

The second case at issue in Ursery involved Charles Wesley Arlt and James Wren, who were convicted of various drug and money laundering charges and sentenced to life imprisonment. Subsequent to the convictions, the United States obtained a civil forfeiture judgment against various property owned or controlled by the defendants. ${ }^{71}$

In both cases, the Courts of Appeals ruled that the imposition of both criminal penalties and civil forfeitures violated the Double Jeopardy Clause. According to the appellate panels, the forfeiture actions at issue constituted "punishment" for purposes of double jeopardy and therefore could not be imposed in addition to the criminal penalties. ${ }^{72}$

The Supreme Court reversed. ${ }^{73}$ While acknowledging that the Double Jeopardy Clause "serves the function of preventing both 'successive punishments... and successive prosecutions,"' Court nevertheless ruled that the forfeiture actions at issue (and civil forfeitures generally) did not constitute punishment, and thus the Double Jeopardy Clause did not apply. ${ }^{75}$ According to the Court, "[s]ince the earliest years of this Nation, Congress has authorized the Government to seek parallel in rem civil forfeiture actions and criminal prosecutions based upon the same underlying events." Further, the Court declared that "a long line" of prior Supreme Court cases had "consistently" concluded that the Double Jeopardy Clause does not apply to civil forfeitures because such forfeitures do not impose punishment. ${ }^{7}$

As in Bennis, the Court reviewed historical precedent. In a 1931 case, Various Items of Personal Property $v$. United States, ${ }^{78}$ the

70. See id. at 271.

71. See id. at 271-72.

72. See United States v. Ursery, 59 F.3d 568, 572-73 (6th Cir. 1995); United States v. $\$ 405,089.23$ U.S. Currency, 33 F.3d 1210, 1221-22 (9th Cir. 1994).

73. The Court was unanimous on the judgment as to Arlt and Wren and was divided eight to one on the judgment as to Ursery, with Justice Stevens dissenting. Justice Kennedy filed a concurring opinion, and Justice Scalia, with whom Justice Thomas joined, filed an opinion concurring in the judgment.

74. Ursery, 518 U.S. at 273 (quoting United States v. Dixon, 509 U.S. 688, 696 (1993)).

75. See id. at 270-71.

76. Id. at 274 .

77. Id.

78. 282 U.S. 577 (1931). 
Waterloo Distilling Corporation had been ordered to forfeit a distillery, warehouse, and denaturing plant on the ground that the corporation had conducted its distilling business in violation of federal law. The government conceded that the corporation had been convicted of criminal violations prior to the initiation of the forfeiture proceeding and admitted that the criminal conviction had been based upon "the transactions set forth ... as a basis for the forfeiture." ${ }^{" 79}$ Nevertheless, the Court found that the forfeiture action did not violate the Double Jeopardy Clause, explicitly acknowledging the history of proceedings against inanimate objects:

[This] forfeiture proceeding ... is in rem. It is the property which is proceeded against, and, by resort to a legal fiction, held guilty and condemned as though it were conscious instead of inanimate and insentient. In a criminal prosecution it is the wrongdoer in person who is proceeded against, convicted, and punished. The forfeiture is no part of the punishment for the criminal offense. The provision of the Fifth Amendment to the Constitution in respect of double jeopardy does not apply. ${ }^{80}$

According to the Ursery Court, at common law a criminal conviction was never considered a bar to civil forfeiture. ${ }^{81}$ Thus, "[f]or the Various Items Court to have held that the forfeiture was prohibited by the prior criminal proceeding would have been directly contrary to the common-law rule, and would have called into question the constitutionality of forfeiture statutes thought constitutional for over a century."

While the Bennis decision devotes one paragraph to discussing a possible rationale underlying forfeiture practice, the Ursery Court nowhere attempts to justify its treatment of civil forfeiture as remedial rather than punitive, beyond the simple fact of historical practice. Instead, the Court emphasizes the dispositive nature of its historical analysis, pointing out that "[e]vidence of a longstanding legislative practice 'goes a long way in the direction of proving the presence of unassailable grounds for the constitutionality of the practice,"”, and that "“[i]n applying a provision like that of double jeopardy, which is rooted in history and is not an evolving concept... a long course of adjudication in this Court carries impressive authority." $\$ 4$

\footnotetext{
79. Id. at 579.

80. Id. at 581.

81. See Ursery, 518 U.S. at 275.

82. Id. at 276.

83. Id. (quoting United States v. Curtiss-Wright Export Corp., 299 U.S. 304, 327-28 (1936))

84. Id. at 278-79 (quoting Gore v. United States, 357 U.S. 386, 392 (1958)).
} 
Although the Court ultimately left open the possibility that certain forfeitures, such as fines, could be deemed punitive ${ }^{85}$ Ursery firmly ruled, based exclusively on the invocation of historical practice, that in rem civil forfeiture is a "remedial civil sanction" that "does not constitute a punishment under the Double Jeopardy Clause." "B6 By stressing the "remedial" nature of these forfeitures, the Court made clear that a forfeiture action is brought on behalf of the community to make it whole rather than simply to provide additional punishment against an individual human being. ${ }^{87}$

\section{The Critics}

While the decisions in Bennis and Ursery fail to illuminate the history on which they rely, the critics of these decisions, and of civil forfeiture generally, have not provided much guidance either. Indeed, those critics who have acknowledged this history have generally done so solely to dismiss forfeiture as an archaic "legal fiction" with irrational roots. Such a perspective ignores any possibility that the history of proceedings against non-human transgressors might provide some insight into forfeiture practice today.

The most extensive published broadside against forfeiture law to date is Leonard W. Levy's A License to Steal: The Forfeiture of Property. ${ }^{88}$ As the title suggests, Levy's work is an excoriation of modern forfeiture practice. As he states bluntly in his preface, "[i]n the case of civil forfeiture, unfairness and injustice always prevail."

Although Levy devotes his first chapter to a review of the history underlying modern forfeiture, it appears that his sole aim in doing so is to expose the purportedly nonsensical roots of the practice. Thus, he makes no effort to understand the law of deodands as anything other than a primitive and pointless custom. Instead, he quotes Blackstone, who dismissed the law of deodands as having a "superstitious purpose" derived from the "blind days of popery."

85. See id. at 280.

86. Id. at 278 .

87. In its most recent pronouncement on forfeiture, United States v. Bajakajian, $118 \mathrm{~S}$. Ct. 2028 (1998), the Supreme Court again invoked the history of actions against inanimate objects to support the conclusion that civil in rem forfeitures are actions against the object, rather than punishment against the individual for an offense. Id. at 2034-35. The Court also reiterated that, "[h]istorically, the conduct of the property owner was irrelevant; indeed, the owner of forfeited property could be entirely innocent of any crime." Id. at 2034. The Court held, however, that the Excessive Fines Clause of the Eighth Amendment governed forfeiture proceedings and then voided as excessive a $\$ 250,000$ forfeiture based on a failure to report currency to customs officials.

88. LEVY, supra note 3.

89. Id. at $\mathrm{x}$.

90. Id. at 15 (quoting 1 William BlaCKSTONe, CoMMENTARIES *300). 
Rather than attempting to understand how the proceedings against animals and inanimate objects might have been viewed in their own time, Levy focuses on various after-the-fact policy justifications offered by Blackstone and other more modern legal commentators. ${ }^{91}$ Not surprisingly, Levy concludes that there is no adequate explanation "why a rational legal system regarded the dumb beast or the inanimate object as a guilty party deserving punishment."'92 Therefore, to Levy, "[t]he law of deodands, like the law of civil forfeiture, was a tissue of legal fictions and contradictions. It was also unjust to its core." ${ }^{93}$

Other forfeiture critics have taken a similar approach. Thus, the history of legal proceedings against non-human transgressors has been described as the root of "the curious and archaic legal fictions upon which all civil forfeitures are premised." 94 The "fiction" that objects can be guilty of crimes has been described as "anachronistic," "as "ancient and obsolete,"96 "repugnant," "perversion." 98 One commentator has labeled this supposed fiction "about as irrational and unjust a proposition as a sober mind can concoct," "99 and another has rejected it as "simply too fantastic to require much rebuttal." forfeiture statutes would almost surely be struck down as unconstitutional were it not for the courts' continued reliance on an ancient common law doctrine that is no longer relevant and is unrecognized in any other segment of our society." ${ }^{101}$ Even those who have sought to defend modern forfeiture laws have acknowledged that the "guilty property fiction ... is an easy target" for critics. ${ }^{102}$

\footnotetext{
91. See id. at 15-19.

92. Id. at 17.

93. Id. at 19.

94. Michelle M. Jochner, The Supreme Court Turns Back the Clock on Civil Forfeiture in Bennis, 85 ILL. B.J. 314, 314 (1997).

95. Tamara R. Piety, Scorched Earth: How the Expansion of Civil Forfeiture Doctrine Has Laid Waste to Due Process, 45 U. MIAMI L. REV. 911, 918 (1991).

96. Lieske, supra note 12 , at 270.

97. Parker-Harris Co. v. Tate, 188 S.W. 54, 55 (Tenn. 1916).

98. W. SEAGLE, THE QUeST For LAW 126 (1941).

99. Jacob J. Finkelstein, The Goring Ox: Some Historical Perspectives on Deodands,
} Forfeitures, Wrongful Death and the Western Notion of Sovereignty, 46 TEMP. L.Q. 169, 257 (1973).

100. Roger Pilon, Can American Asset Forfeiture Law Be Justified?, 39 N.Y.L. SCH. L. REV. 311, 332 (1994); see also Erik G. Luna, Note, Fiction Trumps Innocence: The Bennis Court's Constitutional House of Cards, 49 STAN. L. REV. 409, 419 (1997) ("The concept of guilty property has problems passing the 'laugh test' today.").

101. Lieske, supra note 12, at 267.

102. Richard H. Seamon, "Not Now" Does Not Necessarily Mean "Not Ever": The Supreme Court's Refusal in Bennis v. Michigan to Abandon the "Guilly Property" Fiction of Forfeiture Law, 48 S.C. L. REV. 389, 390 (1997). 
Criticism of the Supreme Court's decisions in Bennis and Ursery has likewise addressed the Court's reliance on history. One commentator argues that "the majority's decision in Bennis turns back the clock from the present to the past, resorting to ancient fictions that have little, if any, relevance today." ${ }^{103}$ Another writer has posited that "none of the original bases of in rem forfeiture have relevance in today's legal proceedings" and criticized the Bennis Court for choosing "to unquestioningly promote the ancient legal fiction of the guilt of inanimate objects." decision has been condemned because it "appears to reinforce [an] antiquated [guilty property] fiction" that "is no longer viable as a justification for powerful and broadly sweeping modern forfeiture laws." 105

What is most remarkable about these criticisms is that none even attempts to understand the legal proceedings against non-human transgressors from the perspective of those who originally took part in the proceedings. ${ }^{106}$ Instead, simply because we now consider it irrational to find an inanimate object or an animal guilty of a crime, these critics assume that this history could not possibly provide a justification for (or even an understanding of) modern forfeiture law. ${ }^{107}$

Thus, both the Court and its critics have failed to seek insight from the very history they invoke to support their positions. Although possible policy justifications are offered or discarded, neither side in the forfeiture debate attempts to ask what type of societal role these proceedings might have played and whether forfeiture might possibly fulfill a similar role today. Accordingly, this history deserves

103. Jochner, supra note 94 , at 320.

104. George M. Dery III, Adding Injury to Insult: The Supreme Court's Extension of Civil Forfeiture to its Illogical Extreme in Bennis v. Michigan, 48 S.C. L. REV. 359, 376 (1997).

105. Sarah Jean Watterson, Note, Putting the Halper Genie Back in the Bottle: Examining United States v. Ursery in Light of Halper, Austin, and Kurth Ranch, 1997 BYU L. REv. 235, 261; see also Kevin Cole, Civilizing Civil Forfeiture, 7 J. CONTEMP. LEGAL Issues 249, 249 (1996) ("[T]he Court's opinion says little about justice; it is largely an assessment of the historical acceptance of forfeiture as a civil remedy."); Ronner, supra note 4, at 766 (In Ursery, "the Court revitalize[d] and deif[ied] the old forfeiture myths that traditionally kept double jeopardy protection at bay.").

106. At least one commentator has gone so far as to ask the appropriate question: "What function did the personification fiction perform, and what is there about deodand that bears any relationship to civil forfeiture which would justify reliance on it?" Piety, supra note 95, at 931. However, she dismisses the inquiry as "unanswerable," id., and falls back on the legal positivist notion that the personification fiction was used simply because it was the law, id. at 931-34. This view, of course, begs the question of the function this particular law might have fulfilled for the community.

107. See, e.g., Mary M. Cheh, Can Something This Easy, Quick, and Profitable Also Be Fair? Runaway Civil Forfeiture Stumbles on the Constitution, 39 N.Y.L. SCH. L. REV. 1, 31-32 ("A fresh look at the reality of forfeiture and judging it by a contemporary understanding of constitutional law ... underlies the requiem for the fiction of 'guilty property'...."). 
a long-overdue second look.

\section{NARRATIVES OF GUILT AND EXPIATION: THE HISTORY OF LEGAL PROCEEDINGS AGAINST INANIMATE OBJECTS AND ANIMALS}

When a transgressor breaches a societal norm, the act, by definition, causes a rift in the social fabric. In response, the community must construct a narrative, ${ }^{108}$ or provide "social meaning"109 for understanding and healing that breach. Anthropologists have long recognized that narratives are the vehicle by which we construct the meaning we take from the world around us. These narratives provide a framework to interpret what we experience and a language for describing reality. "Every telling is an arbitrary imposition of meaning on the flow of memory ... every telling is interpretive."

Narratives are particularly relied upon in times of change, disorientation, and trauma. Thus, a disaster will stimulate "pronouncements, prayers, eulogies, addresses, white papers, and other formal offerings that later dissolve back into the welter of conversation characterizing the ordinary business of living together."111 A society's primary social institutions must function as storytellers at such crisis moments. Religious narratives and their accompanying rituals are the clearest example of an institution constructing meaning out of death and other irrational and frightening events. ${ }^{112}$ The rites link us to our past and future by

108. See supra note 14.

109. Some scholars have preferred to use the term "social meaning" to describe the broad inquiry I encapsulate in the word "narrative." See, e.g., Lawrence Lessig, The Regulation of Social Meaning, 62 U. CHI. L. REV. 943 (1995). But regardless of the label, both concepts are similar attempts "to find a way to speak of the frameworks of understanding within which individuals live; a way to describe what they take or understand various actions, or inactions, or statuses to be; and a way to understand how the understandings change." Id. at 952. Both of these concepts must be distinguished, however, from the idea of a "social norm." Cass Sunstein has defined "norms" as "social attitudes of approval and disapproval, specifying what ought to be done and what ought not to be done." Cass R. Sunstein, Social Norms and Social Roles, 96 COLUM. L. REV. 903, 911 (1996). Although the study of social norms is obviously related to the study of how meaning is constructed (and a social norm is certainly a "narrative" as I use that term), it is important to understand that the issue of social norms centers more on the question of the optimal societal rules for regulating external behavior, whereas I have chosen to pursue a less normative and more psychological account of how people come to apprehend and describe reality, as well as the possible effect these narrative choices might have for the community. Nevertheless, my conclusions may be valuable for those who seek to use forfeiture law to enforce social norms. See infra notes 286-90 and accompanying text.

110. Edward M. Bruner, Experience and Its Expressions, in THE ANTHROPOLOGY OF EXPERIENCE, supra note 14, at 3,9.

111. Robert Hariman, Performing the Laws: Popular Trials and Social Knowledge, in POPUlaR TRIALS: RHETORIC, MASS MEDIA, AND THE LAW 19 (Robert Hariman ed., 1990).

112. See LEVI-STRAUSS, supra note 14 , at 186-204. 
enacting enduring and underlying patterns. ${ }^{113}$ And the narratives provide explanations, or affirmations of faith, or parables, all of which create a framework for understanding the crisis event and healing psychological wounds. Thus, it has been said that cultural narratives provide a "shield against terror." 114

Courts too are social institutions that tell stories about chaotic events. Legal processes provide cultural narratives for imposing order and asserting the primacy of the community. Indeed, the English word "law" derives from Old Norse, where the word not only referred to rules of conduct, but also to the community itself, which shared those laws. ${ }^{115}$ Thus, the term "outlaw" originally described someone who had been expelled from the community and therefore literally stood outside the law. ${ }^{116}$

Banishment is one way in which communities reassert a shared moral order after the breach of a norm. By casting out the transgressor, the community redefines its own boundaries and creates a narrative whereby a tainted element is deemed to be "beyond the pale" of the society. ${ }^{117}$ Through a "status degradation ceremony," 118 the transgressor is "ritually separated from a place in the legitimate order... [and] defined as standing at a place opposed to it."119 Imposing this new degraded status on the transgressor, whether temporarily or permanently, is "a means of demarcating the boundaries between the normative community and those who ha[ve] offended against it." 120

We are familiar with such banishment rituals involving human members of society who breach norms of behavior. These individuals are expelled from public life, usually through incarceration, after first taking part in a legal proceeding that functions as a "status degradation ceremony." However, as this Part demonstrates, various cultures, including our own, have at times taken similar action against non-human actors by creating a narrative whereby an inanimate object or an animal that transgresses the established order is deemed to have committed a crime and is punished as the guilty

113. See KERTZER, supra note 15 , at 9-10.

114. Id. at 4 .

115. See William I. Miller, Of Outlaws, Christians, Horsemeat, and Writing: Uniform Laws and Saga Iceland, 89 MICH. L. REV. 2081, 2082 (1991).

116. See id.

117. Esther Cohen, The Crossroads of Justice: LaW and Culture in Late MEDIEVAL FRANCE 82 (1993).

118. Harold Garfinkel, Conditions of Successful Degradation Ceremonies, AM. J. SoC. 420, $420(1960)$.

119. Id. at 423.

120. COHEN, supra note 117 , at 80 ; see also id. at 77-80 (describing a particular medieval status degradation ceremony known as Chrenecruda). 
party. While it is certainly true that the cultural meaning ascribed to such historical rituals may have been very different from our present conception of guilt and punishment, nevertheless, by focusing on the narratives created in these rituals, we may gain insight about current practice.

This Part begins with a brief survey of historical evidence about the trials of inanimate objects and animals in ancient Greece and then describes English and European trials from the ninth to the nineteenth centuries. We shall see that, for the purpose of these proceedings, it appears to have been irrelevant whether the owner of the transgressing object or animal was at all responsible for the "crime." Rather, these actions were seen as necessary to restore the society's equilibrium, and they were pursued on behalf of the community in proceedings that were wholly separate from any criminal or civil penalties that might lie against the owner. Thus, although modern commentators often refer to these proceedings as resting on a "legal fiction" that non-human actors could be guilty of crimes, there is no indication that these proceedings were actually conceptualized as "fictions" or that somehow the "real" parties before the court were the human owners. Instead, these trials demonstrate the extremes to which communities would go to remove the taint that accompanied a violation of the established order, no matter what form the transgression might take.

\section{A. Appeasing the Furies in Ancient Greece}

On the north side of the Athenian Acropolis stood a building called the Prytaneion, which acted as a ceremonial center of the city and as a site for special social functions. ${ }^{121}$ In addition, a law court located in the building was dedicated to hearing only three kinds of cases: those in which (1) a murderer was unknown or could not be found; (2) a death was caused by an inanimate object; or (3) an animal had killed a human being. ${ }^{122}$

No substantive governmental activity appears to have taken place at the Prytaneion. ${ }^{123}$ Rather, it was "the common hearth of the city, which represented the unity and vitality of the community."

121. See J.J. Finkelstein, The Ox That Gored, 71 AM. PHIL. SoC'Y (pt. 2) 5, 58 (1981); see also JOHN W. JONES, THE LAW AND LEGAL THEORY OF THE GREEKS 256-57 (1977) (using the Latin spelling "Prytaneum.").

122. See Finkelstein, supra note 121, at 58; see also ARISTOTLE, CONSTTTUTION OF AtHens and Related TeXTs 135 (Kurt Von Fritz \& Ernst Kapp trans., Hafner Pub. Co. 1950) ("When [one] does not know who committed the offense, he institutes proceedings against 'the unknown who did the deed.' The [officials at the Prytaneion] conduct prosecution[s] of inanimate things and animals also.").

123. See Finkelstein, supra note 121, at 58.

124. Walter W. Hyde, The Prosecution and Punishment of Animals and Lifeless Things in 
its perpetual fire, colonists would carry sparks to their new homes as a symbol of loyalty and connection with the mother city. ${ }^{125}$ Thus, the Prytaneion appears to have served as the symbol of the community order, and it is not surprising that these legal proceedings against inanimate objects and animals should have occurred there. ${ }^{126}$

Classics scholar Walter Woodburn Hyde has gathered together the few references to the Prytaneion in the extant Greek literature. He concludes that, though ceremonial in character, the trials observed ordinary procedural requirements. ${ }^{127}$ Even jurisdiction was sometimes at issue. In one instance, a boy was killed by a javelin while watching a man practice in the gymnasium. ${ }^{128}$ The court was forced to determine whether the boy, the man, or the javelin was to blame. Only if it were deemed to be a trial of the javelin could the case be heard at the Prytaneion. ${ }^{129}$ Although such questions sound fanciful, they were apparently taken very seriously. According to Plutarch, the great statesman Pericles once spent an entire day arguing with the famous sophist Protagoras about the issue..$^{130}$

This jurisdictional dispute suggests that the action against the object was not conceived as a fiction standing in for a trial against a negligent or guilty owner. Rather, the javelin was considered to be capable of its own guilt, quite apart from the person who threw it, and the community took action to rid itself of the moral taint attaching to the object itself. The proceedings in the Prytaneion, like all other murder trials, took place in the open air so that the judges would not be contaminated by moral pollution emanating from the accused. ${ }^{131}$ And, if the accused were found guilty, the court issued an order banishing the offending object or animal beyond the borders of the city. ${ }^{132}$ Oliver Wendell Holmes observed that the ancient

the Middle Ages and Modern Times, 64 U. PA. L. REV. 696, 696 (1916).

125. See id.

126. Cf. S.C. TOdd, The Shape OF ATHENIAN LAw 275 (1993) ("[The Prytaneion's] functions appear to have been mainly ritual.").

127. See Hyde, supra note 124.

128. See id. at 697-98.

129. See id.

130. See 1 Plutarch's Lives 260 (Arthur H. Clough ed., Everyman's Library, Dutton 1961).

131. See Hyde, supra note 124 , at $696-97$. See generally JONES, supra note 121 , at $254-57$ (discussing the conception of pollution in ancient Greece and methods used to diminish its danger).

132. See JONES, supra note 121, at 256-57; see also, e.g., D.M. MACDOWELL, ATHENIAN HOMICIDE LAW IN THE AGE OF THE ORATORS 86-87 (1963) (quoting Demosthenes (352 B.C.E.) ("[I]f an inanimate object falling on someone hits him and kills him, a trial is held for it in [the Prytaneion] and it is cast beyond the frontier.")); H. MYERS \& J. BRzOSTOWSKI, U.S. DRUG ENFORCEMENT ADMIN., DRUG AGENTS' GUIDE TO FoRFEITURE OF ASSETS 3 (1981) (quoting Aeschines the Greek (389-314 B.C.E.) ("[W]e banish beyond our borders stocks and stones ... and mindless things if they chance to kill a man.")); Finkelstein, supra note 121, at 58 (quoting Pollux (2d century A.D.) ("[The Prytaneion] was presided over by the phylobasileis, 
Greeks banished inanimate objects in precisely the same way that a person would be ostracized for committing a crime. ${ }^{133}$ Thus, after a statue fell on a man, the statue was tried, found guilty, and cast into the sea beyond the borders. ${ }^{134}$ This belief in the guilt of objects even extended to the requirement that, if a person committed suicide, the hand that struck the fatal blow be severed and buried separately from the body. ${ }^{135}$

Evidence exists that many societies throughout the world have conducted similar proceedings and rituals against inanimate objects. Hyde presents examples of actions against trees, rocks, arrows, swords, axes, houses, boats, wooden idols, and even glaciers, for the damage done to mountain valleys. ${ }^{136} \mathrm{He}$ argues that these trials were required to restore the "moral equilibrium" of the community after a killing. ${ }^{137}$

For the Greeks, it was necessary to ascribe guilt and punishment to the offending object or animal lest the Furies, avenging spirits of the dead person, create misfortunes throughout the land. ${ }^{138}$ Indeed, the sense of "moral equilibrium" described by Hyde is expressed frequently in Greek dramas, where plagues, famine, storms, and other misfortunes in the natural world are often attributable to an unexpiated wrong within the society. ${ }^{139}$ Plato goes so far as to view the guilt from a killing as attaching to the family of the deceased, rather than to the accused:

[I]f any lifeless thing deprive a man of life, except in the case of a thunderbolt or other fatal dart sent from the gods - whether a man is killed by lifeless objects falling upon him, or his falling upon them, the nearest of kin shall appoint the nearest neighbor to be a judge and thereby acquit himself and the whole family of guilt. And he shall cast forth the guilty thing beyond the

whose duty it was to remove beyond the border the inanimate object which had fallen upon the man.")).

133. See Holmes, supra note 11 , at 10.

134. See Hyde, supra note 124, at 702.

135. See id.

136. See id. at $724-26$. Hyde states: "The notion ... that lifeless things are ... responsible agents like animals and men, can be evidenced from every stratum of human society from the lowest to the highest." Id. at 724. With only Hyde's anecdotal evidence to support his statement, however, we must regard it as an overly broad generalization.

137. Id. at 698 .

138. See EVANS, supra note 13, at 9. In the last play in Aeschylus's Oresteia trilogy, it is to placate the Furies of the slain Clytemnestra that Athena "remands" the case of Orestes to a human court at Athens, beginning the age of human rather than divine law. See AESCHYLUS, The Eumenides, in ORESTEIA 133, 151-52 (Richmond Lattimore trans., Univ. Chicago Press 1953) (lines 470-89); see also Burt Neuborne, Ghosts in the Attic: Idealized Pluralism, Community and Hate Speech, 27 HARV. C.R.-C.L. L. REV. 371, 372 (1992) ("The Oresteia ushers in the luminous idea of law, not force, as the mediator between self and community.").

139. See, e.g., Sophocles, King Oedipus, in The Theban Plays 25, 26-27 (E.F. Watling trans., Penguin 1947). 
border $^{140}$

The trial was therefore necessary to cleanse the family and, by implication, the community as a whole.

Perhaps most illuminating is the ceremony held each year at the Prytaneion during Roman times, in which an axe was ceremonially tried, declared guilty, condemned, and cast into the sea. ${ }^{141}$ This ceremony was understood to be "in commemoration of the traditional first slaying of an ox on the Acropolis in prehistoric times." 142 Again, it is clear that the action was prosecuted on behalf of the community to remove a symbol of moral guilt so as to redeem the community and establish equilibrium. As with the hand that was severed from the body of a person who committed suicide, so too a guilty object would be seized by the community and symbolically removed from the body politic.

\section{B. "Banishing" Transgressors Through Forfeiture, Excommunication, and Execution in England and Europe}

After the collapse of the Roman Empire, many societies in Europe developed traditions whereby inanimate objects and animals that caused the death of human beings were cast out of the human community. Evidence of these proceedings stretches as far back as the ninth century and continues even into the twentieth century. As with the examples from ancient Greece, there is no indication that these legal proceedings against inanimate objects and animals served as proxies for actions against negligent or culpable owners. Instead, we again see communities constructing narratives of guilt after the breach of a social norm and then creating a symbolic way of cleansing the community to preserve the societal order. ${ }^{143}$

The proceedings against animals and inanimate objects, both in England and on the Continent, appear to derive from the Bible

140. Plato, The Laws 269 (Thomas Pangle trans., Basic Books 1980) (emphasis added); see also LeO Strauss, THE ARGUMENT AND THE ACTION OF Plato's LAws 136 (1975) (arguing that the punishment for such murders "does not serve the purpose of improvement or deterrence but that of expiation of the family of the killed man."). Oddly, Strauss does not mention that the act might be seen as a crime against the community's order, despite his focus on punishment as safeguarding the health of the regime elsewhere in his discussion of murder. See id. at 134.

141. See 3 JAmes G. Frazer, FolK-LORE IN THE Old Testament 421 (1918). According to Hyde, the axe was acquitted each year. See Hyde, supra note 124, at 699 . However, the actual disposition of the axe is immaterial to the basic point that the inanimate object was tried in order to cleanse the community of a moral taint.

142. Hyde, supra note 124 , at 699 .

143. As is clear from this discussion, the various traditions with regard to legal action against inanimate objects and animals appear to have transformed over time, and undoubtedly the cultural meaning ascribed to the rituals changed as well. Nevertheless, the narrative of guilt and the notion of ritual cleansing appear to survive throughout the various permutations of this tradition. 
where, in the Book of Exodus, an ox that killed a human being was sentenced to death by stoning, and its flesh could not be eaten. ${ }^{144}$ The punishment of stoning is a distinctive sentence in the Bible, reserved for only a few types of crimes.

In those cases, there is no designated "executioner," for the community assembled is the common executioner of the sentence. Offenses that entail this mode of execution must therefore be of a character that, either in theory or in fact, "offend" the corporate community or are believed to compromise its most cherished values to the degree that the commission of the offense places the community itself in jeopardy. ${ }^{145}$

The Biblical treatment of the ox indicates that, as in ancient Greece, actions against non-human transgressors were treated as crimes against the community as a whole. Moreover, it was irrelevant whether or not the ox was "morally" guilty. Rather, the guilt was treated as an objective contagion that "must be eradicated in the most public way, and the public must participate in the act of eradication as a demonstration that it is consciously and effectively restoring the order that had been disturbed." 146

In addition to this Biblical command, the English law of the deodand also derived from reaction to the ancient tradition of the blood feud, wherein the kin of the deceased would seek vengeance against whomever was the cause of the death. ${ }^{147}$ To stop the cycle of violence caused by these feuds, communities adopted codes intended to persuade the relatives of the deceased to accept pecuniary compensation rather than exacting their revenge in blood. ${ }^{148}$ This

144. See 1 William Blackstone, COMMENTARIES *301 (likening the deodand practice to the Mosaic law); 3 EDWARD COKE, INSTITUTES OF THE LAWS OF ENGLAND 57 (William S. Hein Co. 1986) (1797) ("And this law concerning deodands is grounded upon the law of God, Exodus 2:28."). Although Jacob J. Finkelstein argues that the stoning of the ox should not be viewed as a form of deodand, he nevertheless acknowledges that the institution of the deodands is in part the result of this Biblical tradition. See Finkelstein, supra note 99, at 180-81.

145. Finkelstein, supra note 121 , at $26-27$. Stoning is also called for in the Bible as a punishment for worshiping foreign gods, being a disloyal son, being a non-virginal bride, and engaging in adultery, child sacrifice, sorcery, necromancy, blasphemy, sedition, and violation of the Sabbath. See id. at 27. "The common denominator of all the offenses entailing the punishment of death by stoning is that they are thought to strike at the moral and religious fibers which the community as a whole sees as defining its essence and integrity. Such crimes, in other words, amount to insurrections against the cosmic order itself." Id. at 27-28.

146. Id. at 58 .

147. See 2 William S. Holdsworth, A History of English Law 43-44 (1927) (discussing the practice of the blood feud).

148. See id. at 44 ("The most obvious method of putting a stop to the feud is to persuade the injured man or the relatives of the deceased to accept some pecuniary compensation."); see also John H. Wigmore, Responsibility for Tortious Acts: Its History, in 3 SELECT ESSAYS IN ANGLO-AMERICAN LEGAL HISTORY 474, 493 (1909) (discussing stages of development in various societies from the blood feud to "mere pecuniary liability"). 
tradition was known as "noxal surrender." was also given both to the lord over the place where the wrong was done and to the lord whose subject had been slain. ${ }^{150}$ These monetary payments implicitly acknowledged that it was not only the victim's kin that needed redress, but the broader society as well: ${ }^{151}$

In the [payment], we can see the germ of the idea that wrong is not simply the affair of the injured individual - an idea which is the condition precedent to the growth of a criminal law. A wrong is regarded as a breach of the [peace] of the king, of a community .... ${ }^{152}$

The various offerings appeased both the kin and the community and therefore restored harmony. ${ }^{153}$

The ninth-century Anglo-Saxon laws of Alfred the Great blended the Biblical tradition with these offerings and created a proceeding resembling forfeiture that later became known as deodand in the English common law. ${ }^{154}$ Under this code, rather than condemning an animal transgressor to death by stoning, the animal was surrendered to the authorities for retribution. ${ }^{155}$ In addition, if a tree fell on someone, the victim's kin were permitted to take the tree in order to expiate the death. ${ }^{156}$ Significantly, the guilty object was given to the kin not as compensation for the loss suffered, but rather as an object upon which their vengeance must be wrought before the dead person could lie in peace. ${ }^{157}$

Ultimately, the Crown replaced the kin as the prosecuting entity. ${ }^{158}$ The word "deodand" derives from the Latin phrase "deo dandum," which literally means "given to God." 159 Thus, the offending object "was forfeited to God, that is, to the King, God's Lieutenant on

149. Finkelstein, supra note 99 , at 181 ; see 2 HOLDSWORTH, supra note 147 , at $52-53$ (discussing deodands after stating that "[w]e have seen that there are some traces in AngloSaxon law of noxal liability").

150. See 2 HOLDSWORTH, supra note 147, at 45 (discussing such payments under AngloSaxon law).

151. See id. at 47.

152. Id.

153. Cf. id. at 45 ("We cannot understand either the amount of the [offering] or the method of its payment unless we remember that it took the place of the feud, and that the feud was always in the background to be resorted to if the money was not paid.").

154. See Richard B. MORRIS, STUdies IN THE History OF AMERICAN LAW 227 (1930).

155. See LEVY, supra note 3, at 10.

156. See Finkelstein, supra note 99, at 181 (linking this practice to noxal surrender).

157. See 2 Frederick Pollock \& Frederic W. MaItland, THE History OF ENGlish LAW 474 (2d ed. 1898).

158. See LEVY, supra note 3 , at 11 ("[T]he guilty object required community atonement by providing compensation to someone in charge, like a chieftain or king. He was the one responsible for keeping the peace that had been shattered by the homicide, even if it was accidental.").

159. Id. at 7 . 
earth, to be distributed in works of charity for the appeasing of God's wrath." ${ }^{160}$ Indeed, the King originally used money collected as a result of the deodand to fund a mass for the dead person's soul, ${ }^{161}$ emphasizing the connection between forfeiture and religious expiation.

Many instances of deodand forfeitures exist in the historical literature. ${ }^{162}$ An early treatise refers to mischances involving falls from trees, ships, boats, carts, horses, and mills, and decrees that the objects causing the death in these cases shall be adjudged deodands. ${ }^{163}$ Another history refers to horses, oxen, carts, boats, millwheels, and cauldrons as the most common deodands. ${ }^{164}$ Thus, for example, a boat that capsized, causing a fisherman to die, was beached, cursed, and allowed to rot ${ }^{165}$ and a horse that carried a man over a cliff or into water, drowning him, was forfeited. ${ }^{166}$

Deodand proceedings were decided by a twelve-person jury, as in trials of human beings. ${ }^{167}$ The jury actively investigated the occurrence to determine whether the object had actually caused the death in question. ${ }^{168}$ If so, the object was forfeited or accursed. ${ }^{169}$ However, inanimate objects involved in the death of a human being were not always found guilty. For example, if a person were thrown from a horse and hit a tree trunk, the horse was guilty, but not the tree ${ }^{170}$ presumably because the tree had not moved during the incident. ${ }^{171}$ Likewise, if an adult "getting up a cart by the wheel to

160. 3 COKE, supra note 144 , at 57; see also 2 POLLOCK \& MAITLAND, supra note 157 , at 473 (quoting Coke as part of their explanation of deodands).

161. See 1 Matthew Hale, The History of the Pleas of the Crown 424 (R.H. Small 1847) (1680) ("Anciently, it seems, when any person came suddenly by his death by the accidental agency of any animate or inanimate chattel, the chattel was to be given to the church for masses for the soul of the deceased.").

162. See, e.g., 1 BLACKSTONE, supra note 144 , at *300-02 (listing examples of deodands); 1 HALE, supra note 161, at 419-24 (same).

163. See 1 BRITTON 39 (Francis M. Nichols trans., Clarendon Press 1865).

164. See 2 POLLOCK \& MAITLAND, supra note 157 , at 473.

165. See LEVY, supra note 3, at 10.

166. See id. at 12.

167. See 1 BLACKSTONE, supra note 47 , at *301 ("[F]or it is no deodand unless it be presented as such by a jury of twelve men.").

168. See 1 HALE, supra note 161, at 419 ("[Deodands] are not forfeit till the death be found, which is regularly by the coroner ... and hence it is, that these goods ... cannot be claimed by prescription, because there must appear a title to them by matter of record, before they are forfeited."); see also 1 BRITTON, supra note 163, at 16 ("And of those drowned in fountains and wells, we will, as in the other cases, that the coroners admit to mainprise the first finders, and enroll their names and the names of their pledges; and of those who have come to their deaths by carts or mills, and in the like cases, let the coroner make his inquests and enrollments as above directed where persons are drowned.").

169. See Hyde, supra note 124 , at 729 .

170. See 3 James F. STEPhen, A History of the Criminal Law of England 77 (London, MacMillan 1883).

171. See 1 BLACKSTONE, supra note 144 , at $* 300-01$ (discussing the difference in treatment under the law of deodand between objects that move and those that do not). 
gather plums" fell and was killed, the wheel was a deodand, but if a child under fourteen fell from a cart or horse, it was not a deodand, "because [the child] was not of discretion to look to himself," and so the cart or the horse could not be blamed. ${ }^{172}$ If, however, a cart ran over a child, or a tree fell and killed him, or a bull gored him, then it was deodand, because it went out of its way to kill him. ${ }^{173}$

In determining which object to count as a deodand, fine distinctions were sometimes made. For example, if a person were carried under the wheel of a mill, the wheel would be forfeited, but not the entire mill. ${ }^{174}$ Similarly, "[i]f a weight of earth fall upon a worker in a mine and kill him, the weight of earth is forfeit, not the whole mine." 175 However, if a tree fell, hitting the branch of another tree, and that branch in turn hit a person, both the falling tree and the arguably innocent branch were forfeited. ${ }^{176}$

The law of deodands migrated to the American colonies and entered the legal annals of this country as well. ${ }^{177}$ Thus, an inquest before a jury was held on January 31,1637 , regarding the body of a planter who had been felled by a falling tree. According to the trial record, "the jurors aforesaid, upon their oath aforesaid, say that the said tree moved to the death of the said John Bryant; and therefore find the said tree forfeited to the Lord Proprietor." ${ }^{178}$ Likewise, under a Massachusetts statute of 1648, a dog that killed sheep could be hanged. ${ }^{179}$ One commentator reports that, at least through the eighteenth century, deodand forfeitures appear to have been accepted in this country as "routine procedure." ${ }^{80}$ In early colonial vice admiralty courts, ships were treated as if they were alive, and

172. 1 HALE, supra note 161 , at 422 .

173. See id.

174. See id. at 420 .

175. Id.

176. See id. at 419.

177. See MORRIS, supra note 154, at 227; Cyrus H. Karraker, Deodands in Virginia and Maryland, 37 AM. HIST. REV. 712, 713 (1932) ("Deodands occurred, it seems, in all the colonies."); see also THE EARLIEST ACTS AND LAWS OF THE COLONY OF RHODE ISLAND AND ProvidenCe Plantations 1647-1719, at 61 (John D. Cushing ed., 1977) (quoting a 1663 law: "For as much as A man may be Slaine by other cafsulties then by the Hand of A man ... ye thing yt accafsioned his Death... shall be seized... \& taken as ye Deodands are in England ....").

178. MORRIS, supra note 154, at 227 (quoting 4 ARCHIVES OF MARYLAND 9, 10 (W.F. Browne ed., 1883)).

179. See id. at 229. In addition, if the owner had knowledge of the dog's dangerous habits, the owner would pay a fine over and above the forfeiture of the animal, see id, again suggesting that the action against the animal was considered to be wholly separate from any possible action against the owner. Although the action against the dog can be seen as a safety precaution to remove a dog that might still be dangerous, such an explanation does not account for why a legal proceeding, or indeed a public hanging, was thought necessary.

180. Id.; see also Karraker, supra note 177, at 712-17 (discussing deodand practice in Virginia and Maryland). 
prosecutions were initiated against vessels by name. As Holmes observed: "It is only by supposing the ship to have been treated as if endowed with personality, that the arbitrary seeming peculiarities of the maritime law can be made intelligible." ${ }^{81}$

In continental Europe, legal proceedings against animals constructed a similar narrative of guilt attaching to a non-human actor. ${ }^{182}$ When a domesticated animal caused the death of a human being, the beast was treated in all ways possible as a human criminal. Animals were confined in human prisons and subjected to the same treatment as human prisoners. ${ }^{183}$

Once the trial began, it too was conducted just as if the defendant were a human being. Both the prosecution and defense were represented by professional advocates. ${ }^{184}$ Witnesses and evidence were heard prior to punishment. And though the animals were usually found guilty, such a verdict certainly was not assured. For example, in 1457 the sucklings of a sow that had murdered a fiveyear-old child were included in the indictment. They had been found at the scene of the crime stained with blood, but "in lack of any positive proof that they assisted in mangling the deceased, they were restored to their owner, on condition that he should give bail for their appearance, should further evidence be forth-coming to prove their complicity in their mother's crime." ${ }^{185}$ Likewise, in 1750 a man and a donkey, discovered in an act of copulation, were both charged with bestiality, but while the man was sentenced to death, the donkey was subsequently acquitted on the ground that she was the victim of violence and had not participated in her master's crime of her own free will. ${ }^{186}$ At trial, the defense had presented a statement signed by many inhabitants of the commune stating that they had known the donkey for four years, that she had always shown herself to be virtuous and well-behaved both at home and abroad, and that she had never given occasion of scandal to anyone. Therefore, "they were willing to bear witness that she is in word and deed and in all

181. HoLMES, supra note 11 , at 25 . Although some commentators point out that admiralty seizures and deodand forfeitures were different types of actions under the English common law, see supra note 11, both employ the idea that objects can be guilty of a crime and therefore can be linked for the purposes of this analysis.

182. For a more complete discussion of these animal trials, see generally Paul Schiff Berman, Rats, Pigs, and Statues on Trial: The Creation of Cultural Narratives in the Prosecution of Animals and Inanimate Objects, 69 N.Y.U. L. REV. 288 (1994).

183. See, e.g., id. at 299-300 (describing the confinement of an animal in a human prison in the town of Pont de Larche).

184. See, e.g., EVANS, supra note 13, at 38 (noting the appointment of a defense lawyer for a group of insects in a 1545 trial).

185. Id at 153-54.

186. See id. at 150. 
her habits of life a most honest creature." 187 This document seems to have had a decisive influence upon the judgment of the court. ${ }^{188}$

If the animal were found guilty, it was executed. Even the customs for punishment were the same for animals and human beings. The usual method was hanging, although there are also recorded instances of animals being burnt at the stake or buried alive. ${ }^{189}$ Sometimes the animal was actually dragged through the streets, as was the practice with a human criminal. ${ }^{190}$ If it managed to escape, an effigy. was burned, again mirroring the treatment of human defendants. ${ }^{191}$ Animals were even put in the rack prior to the execution in order to extort confessions. ${ }^{192}$ "It is not to be supposed that, in such cases, the judge had the slightest expectation that any confession would be made; he wished merely to observe all forms prescribed by the law, and to set in motion the whole machinery of justice before pronouncing judgment." 193

In contrast to the murder and bestiality cases, many other trials of animals involved large groups of pests that caused hardship throughout the community or created a public nuisance. In these instances there was neither a single victim nor one animal to hold responsible, and the entire rural commune prosecuted the case. ${ }^{194}$ Because no individual could be punished, these trials often ended with an ecclesiastical tribunal placing anathemas ${ }^{195}$ and excommunications on the guilty parties. Again, advocates were hired to represent the animals, and the trials often dragged over long periods of time as defense counsel raised numerous objections ranging from a claim of insufficient notice ${ }^{196}$ to the argument that the animals were simply obeying God's command to seek sustenance on Earth, thereby immunizing them from human punishment. ${ }^{197}$

Although some commentators have attempted to justify the practice of trying inanimate objects and animals as a form of punishment for negligent owners, ${ }^{198}$ the proceedings themselves refer

187. Id.

188. See id. at 150-51.

189. See id. at 147.

190. See COHEN, supra note 117, at 113.

191. See id.

192. See EVANS, supra note 13, at 139.

193. Id.

194. For an example of such a proceeding, see Berman, supra note 182 , at 310-13.

195. Anathemas were formal ecclesiastical curses, usually accompanied by excommunication. See WeBSTER's THIRD NEW INTERNATIONAL DICTIONARY 78 (1986).

196. See, e.g., Berman, supra note 182, at 289 .

197. See, e.g., id. at 311.

198. See, e.g., 1 BLACKSTONE, supra note 144, at *301 ("[Some deodands are] grounded upon this additional reason, that such misfortunes are in part owing to the negligence of the owner, and therefore he is properly punished for such forfeiture."); 1 HALE, supra note 161, at 
repeatedly to the offending agent as the guilty party and nowhere adopt a narrative invoking negligence principles. To the contrary, one court observer during the reign of Henry VIII stated: "Where a man killeth another with the sword of John at Stile, the sword shall be forfeit as deodand, and yet no default is in the owner."'199

Indeed, the prosecution of the guilty object sometimes substituted for any criminal action against the human malefactor. ${ }^{200}$ Thus, it was said that "[i]f a man by misadventure is crushed or drowned or otherwise slain, let hue and cry at once be raised; but in such a case there is no need to make pursuit from field to field and vill to vill; for the malefactor has been caught, to wit, the bane [the slaying object]." ${ }^{201}$ Even on those occasions when a human being was tried for murder, the forfeiture of the object that caused the death was a separate part of the proceedings. ${ }^{202}$

Oliver Wendell Holmes, in his noted survey of the common law, observed that the deodand actions were not based on the fault of the owner. Holmes pointed out that, if they had been, then the forfeiture would be pursued against the individual who was the owner at the time the object or animal did the harm. However, that was not the case. Rather, "[t]he action followed the guilty thing into whosoever hands it came." ${ }^{203}$ Thus, if an animal had been sold to a new owner by the time the action was brought, the new owner still lost possession of the transgressing beast, despite having no possible responsibility at the time of the transgression. ${ }^{204}$ Likewise, an object could be forfeitable even if it were the property of the person who had died. ${ }^{205}$

424 ("The notion upon which deodands have been principally levied in our own times, and which appears indeed to have been always considered as, partly, the reason of the law, has been that they operate as a sort of penalty on carelessness, tending to make the owners of chattels of a dangerous character, more cautious in using them.").

199. Quoted in HOLMES, supra note 11, at 23 (citing "a book written in the reign of Henry VIII, about 1530"); see also MORRIS, supra note 154, at 229 (recounting a 1680 forfeiture of a horse that killed a person despite the owner's claim that he did not know the horse was "ill Condicioned").

200. While it is certainly true that an action against a guilty object or animal might therefore function as a substitute punishment for the owner, the important point is that the two guilts were conceptualized as distinct from each other. Moreover, as discussed infra, had the forfeiture been treated solely as punishment against a negligent owner, then forfeiture would have been pursued against the individual who was the owner at the time the object or animal caused the harm. However, as Oliver Wendell Holmes has noted, that was not the case. See HOLMES, supra note 11, at 11.

201. 2 POLLOCK \& MAITLAND, supra note 157, at 473.

202. See 1 BLACKSTONE, supra note 144 , at *301 ("[I]n all indictments for homicide, the instrument of death and the value are presented and found by the grand jury ... that the king or his grantee may claim the deodand ....").

203. HoLMES, supra note 11 , at 11 .

204. See id. at 24. This idea still survives in the "relation back" doctrine in modern civil forfeiture, whereby the government's right to the property is deemed to arise at the time of the illegal use. The "relation back" doctrine, as in Holmes's examples, requires forfeiture even if the object were subsequently sold to a new owner. See LEVY, supra note 3, at 105.

205. See 2 POLLOCK \& MAITLAND, supra note 157, at 474; see also Karraker, supra note 
Proceedings against animals and inanimate objects appear to have continued into the modern era. When the British finally abolished deodands in $1846,{ }^{206}$ one member of Parliament remarked that the law of deodands was still being "called into action weekly." Moreover, just as the movement to abolish deodands was gathering momentum in England, ${ }^{208}$ the Supreme Court of the United States, in The Palmyra ${ }^{209}$ and Harmony, ${ }^{210}$ adopted the concept of finding objects guilty, ${ }^{211}$ thereby insuring that the tradition would endure. And sociologist E.P. Evans, who has gathered the most complete listing of animal trials to date, cites over two hundred cases occurring between 824, when moles were tried in the valley of Aosta, ${ }^{212}$ and 1906 , the year of his writing, when a dog was sentenced to death in Switzerland. ${ }^{213}$ As recently as 1994, the Governor of New Jersey banished from the state a dog that had bitten a person, ending the dog's three-year incarceration on death row. ${ }^{214}$

\section{FORFEITURE'S SYMBOLIC NARRATIVE AND CURRENT FORFEITURE DOCTRINE}

Philosopher Wilhelm Dilthey wrote that "reality only exists for us in the facts of consciousness given by inner experience." ${ }^{215}$ But for every experience there is a wide range of possible meanings that can be assigned. ${ }^{216}$ And for every possible meaning there are a wide range of stories one can tell. Thus, the way in which we describe or conceptualize an experience ultimately creates the meaning we

177, at 714-15 (discussing deodand forfeiture of the chain on which a person hanged himself).

206. For a discussion of the abolition of deodands in England, see Finkelstein, supra note 99, at 170-71.

207. LEVY, supra note 3, at 19.

208. See Finkelstein, supra note 99, at 171-72 (tracing the "crisis" that developed beginning in the early 19th century regarding an increase in wrongful deaths due to the advent of stagecoaches and railroads, and arguing that this crisis led to the abolition of deodands).

209. 25 U.S. (12 Wheat.) 1 (1827).

210. 43 U.S. (2 How.) 210 (1844).

211. See supra text accompanying notes $32-36$.

212. Evans identifies place names by province or town, presumably based on the name listed in the actual court records. Since some of these towns may no longer exist or may have changed names, it is often difficult even to identify the present-day country that corresponds to Evans's appellations.

213. See EVANS, supra note 13, at 265-86 (listing proceedings).

214. See Robert Hanley, Taro Leaves Death Row, Jail, and New Jersey Soil, for Good, N.Y. TIMES, Feb. 11, 1994, at B4; see also Jeff Stryker, The Dog Walks, N.Y. TimES, Feb. 3, 1994, at A21 (comparing the case to medieval animal trials). Although the dog was never formally charged with a crime or put on trial, the banishment mirrors the Greek custom of exiling guilty objects beyond the boundaries of Athens.

215. Wilhelm DiltheY: Selected Writings 161 (H.P. Rickman ed. \& trans., Cambridge Univ. Press 1976).

216. See KERTZER, supra note 15, at 3-4 ("Human reality is not provided at birth by the physical universe, but rather must be fashioned by individuals out of the culture into which they are born."). 
discover in that experience. ${ }^{217}$ "All we ... have to work with is the presentation of events in the vehicle of narrative discourse."218 Therefore, "our understanding of events as they happened out there, in the world, is an inference we make, a normalized chronology and causality we intuit from what the narrative tells us."219

If legal proceedings function, at least in part, as cultural storytellers, then it is essential not only to explain the rationale behind a given legal proceeding, but also to take seriously the way in which the proceeding constructs reality through its narrative. ${ }^{220}$ Unfortunately, from the beginning, commentators have ignored the narrative constructed by trials of non-human transgressors. These commentators have rejected the idea put forward in the trials that inanimate objects and animals could indeed be considered guilty of crimes and have instead sought more "rational" explanations for the longevity of the practice. This Part begins with a brief survey of these purported rationales and argues that, although the various justifications may well have some validity, they are necessarily incomplete because they require the commentator to discount the language of the proceedings themselves.

Thus, instead of viewing these trials as built on a legal fiction, we must consider the idea that the object or animal was actually conceived of as a guilty party. Accordingly, this Part discusses these trials as "status degradation ceremonies" that served to reinforce the communal order by casting out a transgressor. In this view, the nonhuman instrument of death or destruction is considered to be tainted by the incident and is therefore symbolically forfeited in an action independent of any proceeding against a culpable human being. Finally, this Part returns to the Supreme Court's decisions in Bennis and Ursery to see whether any aspect of this narrative survives in contemporary American forfeiture doctrine.

217. See Edward M. Bruner, Experience and its Expressions, in THE ANTHROPOLOGY OF EXPERIENCE, supra note 14, at 3, 7-12.

218. Brooks, supra note 14 , at 17 .

219. Id.; see also DAVID CARR, TIME, NARRATIVE, AND HISTORY $57-72$ (1986) (arguing that narrative is not something we impose onto the events and phenomena we experience, but is rather the way we experience those events and phenomena).

220. Indeed, Lawrence Lessig goes so far as to claim that social meanings so construct the dominant reality of a society that they are "in an important sense nonoptional. They empower or constrain individuals, whether or not the individual chooses the power or constraints." Lessig, supra note 109 , at 955 . While such a formulation may over-emphasize somewhat the powerlessness of individuals to forge new social constructions of reality, there can be no doubt that narratives, or social meanings, are "forces to be reckoned with, by the weakest as well as the strong." Id. (internal quotation marks and footnote omitted). 


\section{A. Explanations and Justifications for Legal Proceedings Against Inanimate Objects and Animals}

From the outset, scholarly criticism accompanied the practice of trying inanimate objects and animals. The earliest commentary on animal trials in Europe is found in a treatise by Philippe de Beaumanoir from 1283. ${ }^{221}$ Beaumanoir condemned the practice as juridically meaningless and invalid, because he believed that all crime presupposes intent, and beasts possessing neither knowledge of good and evil nor malicious intentions could not be held responsible for their actions. ${ }^{222}$

This argument was a recapitulation of positions taken by other critics. Earlier in the thirteenth century, Thomas Aquinas, in his Summa Theologiae, questioned whether it was even permissible to curse irrational creatures. ${ }^{223} \mathrm{He}$ argued that curses and blessings could only be pronounced on beings capable of receiving evil or good impressions from them, and so such spells should be aimed only at rational and sentient beings. ${ }^{224}$ Because animals were devoid of understanding, they could not, in Aquinas's view, commit a wrong. ${ }^{225}$ Although he acknowledged the existence of Biblical spells visited upon non-rational beings, Aquinas explained that these curses were actually aimed at human beings who would be directly affected. ${ }^{226}$ For example, when God cursed the earth, the true targets were human beings who would be punished by its sterility. ${ }^{227}$ Aquinas concluded that, if animals are regarded as creatures coming from the hand of God and employed by Him as agents for the execution of His judgments, then cursing them constitutes blasphemy. ${ }^{228}$ On the other hand, if animals are treated as lesser, non-rational creatures, then cursing them is "idle and vain and consequently unlawful.",229

Most ecclesiastical opinion agreed with Aquinas. If animals were ravaging the communities, it must be the devil's work, and so the proper course of action was for the people to repent their sins rather

221. See BEAUMANOIR, supra note 16; see generally ADHEMAR ESMEIN, A HISTORY OF Continental Criminal Procedure 611 (John Simpson trans., Little, Brown 1913) (finding Beaumanoir's work valuable for acquainting readers with the legal institutions of the period); O.F. ROBINSON ET AL., AN INTRODUCTION TO EUROPEAN LEGAL HisTORY 335 (1985) (describing Beaumanoir's Coutumes as one of the important unofficial compilations of territorial customs in areas of France).

222. See BEAUMANOIR, supra note 16 , at $\S 1944$.

223. See 3 St. Thomas Aquinas, Summa Theologiae 1505 (2a-2æ, q. 76) (Fathers of the English Dominican Province trans., Christian Classics 1948).

224. See id.

225. See id.

226. See id.

227. See id.

228. See id.

229. Id. 
than put the animals on trial. ${ }^{230}$ Indeed, defense counsel at many of these trials argued that, because the pests clearly were sent to punish sinful human beings, they should be regarded as agents of God, making it useless and indeed blasphemous to prosecute them. Instead, repentance would be the only effective means of combating the beasts, for only then might God remove the scourge. ${ }^{231}$

The evidence indicates, however, that this argument rarely prevailed at trial. Instead, the validity of animal prosecutions was upheld, and the trials were combined with various rites of religious purification. Thus, prior to any trial that might involve an exorcism, the entire commune formed processions of prayer and repentance. It was only if these religious means failed that the trial could begin. ${ }^{232}$

These activities might seem to indicate that animals were punished because they were seen as the embodiment of Satan. However, the sentences against the animal pests usually stated only that the animals were harming human beings, not that they were agents of the devil. ${ }^{233}$ Even the precedents cited were invariably curses of earthly animal nuisances, with no mention of any supernatural element at work. ${ }^{234}$

The English law of the deodand also faced strong criticism. As early as the thirteenth century, Henry de Bracton, in his discussion of the laws of England, opined that the deodand practice was unreasonable. ${ }^{235}$ Pollock and Maitland attributed the proceedings against inanimate objects to "that unreasoning instinct that impels the civilised man to kick, or consign to eternal perdition, the chair over which he has stumbled." proceedings as the product of "the animism of primitive man."237 According to this theory, human beings erroneously endowed objects with both a soul and human (or superhuman) mental facilities. ${ }^{238}$ However, as discussed in Part II, the common law of the deodand developed from the Biblical command regarding the goring ox and the Gothic tradition of "noxal surrender," whereby the kin of the deceased took vengeance on a symbolic object rather than perpetuate a blood feud. Neither of these sources appears to rely on

230. See COHEN, supra note 117 , at 126.

231. See EvANS, supra note 13, at 52-53.

232. See COHEN, supra note 117, at 131 (describing instructions from the bishop of Autun to parishioners regarding rituals to be performed in connection with a trial of snails).

233. See id. at 130 .

234. See id.

235. See 2 HOLDSWORTH, supra note 147 , at 259 .

236. 2 POLLOCK \& MAITLAND, supra note 157 , at 474.

237. Finkelstein, supra note 121, at 48 (quoting HANS KELSEN, General THEORY OF LAW AND STATE 3-4 (Anders Wedberg trans., Harvard Univ. Press 1945)).

238. See id. 
the notion that the object or animal acted with some kind of guilty intent, as a human being might. Thus, animism is, at best, an incomplete explanation.

Blackstone, while dismissing the "superstitious" origins of deodands as derived from "the blind days of popery," nevertheless attempted to justify the practice on the ground that it helped to deter negligence..$^{239}$ Under this theory, misfortunes leading to accidental death were partly the result of "the negligence of the owner" of the property, "and, therefore, he is properly punished by such forfeiture. ${ }^{240}$ Hale similarly expressed the idea that forfeiture of the deodand induced better care..$^{241}$ While this justification continues to resonate in some of the modern Supreme Court forfeiture opinions, ${ }^{242}$ it too provides only a partial account, for, as Holmes pointed out, if the object or animal had been sold prior to forfeiture, the new owner would suffer the loss, not the allegedly culpable owner. ${ }^{243}$ In addition, even objects owned by the victim were sometimes considered deodand. ${ }^{244}$

The Supreme Court has, on occasion, offered one further justification for the forfeiture tradition. In certain circumstances it is very difficult both to track down the owner of an object that has caused harm and to determine whether the owner actually knew about the illegal activity. Thus, by proceeding against the object in rem, the government is spared the difficulty of finding the owner or proving the owner's guilt. ${ }^{245}$ Although this justification may or may

239. 1 BLACKSTONE, supra note 144 , at $* 300-01$.

240. Id. at *301. Even Blackstone recognized, however, that the object itself was considered "an accursed thing," thereby suggesting that, through forfeiture, the object was purified and lost its taint.

241. See 1 HALE, supra note 161, at 424 ("The notion upon which deodands have principally been levied in our own times, and which appears indeed, to have been always considered as, partly, the reason of the law, has been that they operate as a sort of penalty on carelessness, tending to make the owners of chattels of a dangerous character, more cautious in using them.").

242. See, e.g., Calero-Toledo v. Pearson Yacht Leasing, 416 U.S. 663, 685-86 (1974) (quoting J.W. Goldsmith, Jr.-Grant Co. v. United States, 254 U.S. 505, 510-11 (1921) ("[S]ome forms of property are facilities, and therefore... Congress interposes the care and responsibility of their owners in aid of the prohibitions of the law and its punitive provisions, by ascribing to the property a certain personality, a power of complicity and guilt in the wrong.").

243. See HOLMES, supra note 11, at 11; see also id. at 23-24 ("[I]t has been repeated from Queen Elizabeth's time to within one hundred years, that if my horse strikes a man, and afterwards I sell my horse, and after that the man dies, the horse shall be forfeited." (footnotes omitted)).

244. See 2 POLLOCK \& MAITLAND, supra note 157 , at 474.

245. See, e.g., Bennis v. Michigan, 516 U.S. 442, 472 (1996) (Kennedy, J., dissenting) ("[T]he necessity of finding some source of compensation for injuries done by a vessel whose responsible owners were often half a world away and beyond the practical reach of the law and its processes .... and the impracticality of adjudicating the innocence of the owners or their good-faith efforts in finding a diligent and trustworthy master, combined to eliminate the owner's lack of culpability as a defense."); Van Oster v. Kansas, 272 U.S. 465, 467-68 (1926) 
not be sensible as a policy matter, it is, like the negligence theory, an inadequate description of the history of deodands. There is no indication that these proceedings were conceived as a form of strict liability penalty for particularly dangerous items. Moreover, this theory still does not explain why an object causing harm to its owner would nevertheless be considered a deodand.

Finally, modern critics have pointed out that deodands provided a source of income to the king and his feudal lords, explaining the longevity of the practice on economic grounds. ${ }^{246}$ However, as historian Esther Cohen points out, killing an animal often deprived the king and the feudal lords of revenue. ${ }^{247}$ It is difficult to see the economic benefit to be gained from the forfeiture of a wheel or a tree branch or a clod of dirt. Similarly, in Bennis, the seizure of the car was not an economic benefit for the government. Indeed, the trial court found that there were no net proceeds from the sale of the car ${ }^{248}$ More importantly, even if the ultimate longevity of the practice is explicable partially on economic terms, the particular language used to conceptualize the proceeding is not. Thus, it may be less important to explain why the practice survived than to examine the narrative of guilt that surrounded the practice and the social meaning that this narrative created.

Indeed, although all of these varied theories about the trials of inanimate objects and animals undoubtedly have some explanatory value, none provides a completely satisfactory account of the practice because none attempts to understand the trials on their own

("The law... precludes evasions by dispensing with the necessity of judicial inquiry as to collusion between the wrongdoer and the alleged innocent owner."); Harmony v. United States, 43 U.S. (2 How.) 210, 233 (1844) (forfeiture applies "without any regard whatsoever to the personal misconduct or responsibility of the owner thereof. And this is done from the necessity of the case, as the only adequate means of suppressing the offense or wrong, or insuring an indemnity to the injured party.").

246. See, e.g., Finkelstein, supra note 99, at 182. Nevertheless, even Finkelstein acknowledges that "a notion of [guilt] might have played some role in the development of the institution." Finkelstein, supra note 121 , at 74 . Hyde rejects economics as the primary motivation for the practice, arguing that the real object of the deodand was to atone for manslaughter in accordance with medieval concepts of justice. See Hyde, supra note 124, at 728.

247. See COHEN, supra note 117 , at 115 :

The execution of an animal was just as expensive as that of a man, especially in small jurisdictions requiring the services of [a] hangman from another town. The hangman's travel and time costs in such a case would also have been charged to the judicial authority. While the beast's owner lost, the lord stood to gain no material profits.

248. See Bennis, 516 U.S. at 445. According to the District Attorney in the case:

[T] he charge to tow a vehicle off the street was $\$ 75$ and to store it was $\$ 8$ per day. The state of Michigan charged $\$ 11$ to transfer title to a buyer at auction. The salvage company charged $\$ 60$ to hold the auction. Forty-three days had already elapsed by the entry of the trial court's order. Given these unit costs, the trial judge properly estimated expenses in the Bennis case to be in excess of the car's value.

George E. Ward, Bennis and the War Against Drugs, 46 CATH. U. L. REV. 109, 114-15 (1996) (footnotes omitted). 
terms. After all, these proceedings were public spectacles, conducted with the active participation of the community. ${ }^{249}$ The trials not only adjudicated conflicts but also constructed a way of understanding and coming to terms with grave misfortunes or freak accidents. Thus, even if one or a combination of the theories described above explains why these trials persisted, those theories do not help us to see the possible cultural significance embedded in the narrative of guilt that the trials constructed.

\section{B. Narratives of Degradation}

Most modern writers who have discussed the social function of trials have emphasized the courts' chief role as dispute resolvers. ${ }^{250}$ However, it is important to see that trials also function as cultural storytellers and that legal processes provide narratives that permit the community to respond to the breach of a social norm. ${ }^{251}$ Thus, trials not only redress the harm to a community by punishing a guilty individual; they also "perform the laws"252 so that the community can reenact a sense of its own order and redraw its boundaries. The tainted transgressor is therefore reduced in status, reclassified as an "other," and symbolically removed from the polity.

Social scientist Harold Garfinkel has called this type of ritual a "status degradation ceremony," defined as "[a]ny communicative work between persons, whereby the public identity of an actor is transformed into something looked on as lower in the local scheme of social types."253 According to Garfinkel, the act of expressing

249. See COHEN, supra note 117 , at 74 :

$[\mathrm{T}]$ he public watching legal rituals was, despite its ostensible passivity, perhaps the most important element in the entire picture. Unless the spectacle spoke the language of the audience, used its symbols and cultural perceptions, the entire purpose of the exercise was lost. The judge in his gallery viewing a stage set at his orders and the spectator in the crowd looking, jostling and being jostled, shouting assent or dissent, were both participants in the legal drama.

250. See, e.g., Theodore Becker, Comparative Judicial Politics: The Political FUNCTIONINGS OF COURTS 26 (1970) (viewing disputes as the justification and focus of court work and therefore stressing impartiality as "the heart of the judicial process"); DISPUTES AND THE LAw (M. Cain \& K. Kulcsar eds., 1983) (arguing that the more complex the society, the greater the need for disputes to have institutionalized resolutions according to legal patterns); J.A.G. GRIFFITH, THE POLITICS OF THE JUDICIARY 220 (1981) (discussing British courts as fora for resolving political controversies); Richard L. Abel, A Comparative Theory of Dispute Institutions in Society, 8 L. \& SoC'Y REV. 217 (1973) (describing courts as primarily disputeresolving institutions); M. Cain \& K. Kulcsar, Thinking Disputes: An Essay on the Origins of the Dispute Industry, 16 L. \& SOC'Y REV. 375 (1982) (arguing that any general theory about disputes should begin with the presumption that courts should settle disputes); Simon Roberts, The Study of Dispute: Anthropological Perspectives, in DISPUTES AND SETTLEMENTS 1 (John Bossy ed., 1983) (discussing different ways dispute-resolving institutions intervene in quarrels).

251. See Berman, supra note 182, at 314 (describing trials as "performative rituals that allow a community to respond to the breach of a social norm").

252. Hariman, supra note 111.

253. Garfinkel, supra note 118 , at 420. 
moral indignation towards a transgressor of the established order reinforces group solidarity. Indeed, he describes a degradation ceremony as "a secular form of communion." 254

A degradation ceremony can be particularly useful in cases where the transgressor is not a human being. When statues fall from the sky or pigs kill a small child or the branch of a tree crushes someone, there is a sense of disorder and irrationality that the society's institutions must address: "Such random acts of violence caused by insensate agents bring a deep feeling of lawlessness: not so much the fear of laws being broken, but the far worse fear that the world might not be a lawful place at all."255 By permitting the community to reaffirm its boundaries and reestablish its solidarity, a status degradation ceremony helps to impose order on a world of random violence. And while it is unclear whether communities considered the guilty animals or inanimate objects actually to have lost status as a result of legal proceedings against them, it is significant that these proceedings mirrored the trials of human perpetrators and relied on the same ritualized forms of justice. Therefore, the form of the status degradation ceremony, with its focus on community purification, was retained.

The legal proceedings against inanimate objects and animals discussed in Part II thus can be understood as status degradation ceremonies that helped to heal the community in at least two ways. First, the trials asserted the moral order of the community by defining the offending animal or object as guilty of a crime. Then, the proceedings performed an act of purification by removing the transgressor from the community, either through banishment, forfeiture, excommunication, or execution. And although action might also be taken against a human agent involved in the killing, such action was seen as entirely distinct from the proceedings against the non-human agent. As in the forfeiture of the sword owned by John at Stile, ${ }^{256}$ the blight on the community included both the agent of lawlessness and the symbolic object.

\section{Symbolic Forfeiture and the Supreme Court}

To many observers, the Supreme Court's decision in Bennis $v$. Michigan was both irrational and inexplicable. Indeed, the holding unleashed a torrent of media criticism, ${ }^{257}$ and law review articles as

254. Id. at 421 .

255. Humphrey, supra note 13 , at xix.

256. See supra text accompanying note 199.

257. See, e.g., Robin E. Blumner, Perspective, Moving One Step Closer to a Police State, ST. Petersburg TIMES, Mar. 17, 1996, at 4D; Editorial, Government's Grand Seizures, DET. NEwS, Mar. 13, 1996, at 8A; Richard Grossman, As a Matter of Law Seizure Ruling Belongs in 
well have been largely negative. ${ }^{258}$ Most commentators have focused on the Court's indifference to the impact that its opinion would have on innocent third parties. One writer contended that "the seizure of a woman's car because of her husband's one-time peccadillo sounds excessive to me. And not just excessive: cruel, unusual, and damned embarrassing besides." 259 Another editorialist excoriated the Court for sanctioning the practice of "steal[ing] property from innocent people." ${ }^{260}$ The New York Times and The Washington Post agreed that the decision violated elementary notions of "fairness." "61

For some, "the most surprising thing about the Bennis decision was Justice Ginsburg's vote."262 Because she is considered part of the Court's so-called "liberal wing," it was widely expected that she would side with Justices Stevens, Souter, and Breyer, all of whom dissented (along with Justice Kennedy). Instead, Justice Ginsburg joined Chief Justice Rehnquist's opinion for the Court-along with Justices O'Connor, Scalia, and Thomas-and helped to tip the scales against Tina Bennis, by a margin of five to four. Her vote prompted

19 th Century, POST STANDARD (Syracuse, N.Y.), Mar. 11, 1996, at A8; Charles Levendosky, High Court Takes Low Road on Forfeiture, DAYTON DAILY NEWS, Mar. 14, 1996, at 15A; Nasty Attack of Seizure, TIME, Mar. 18, 1996, at 80; Nation's Founders Would Gasp at Court's Stance, USA TODAY, Mar. 5, 1996, at 10A; Matthew J. Norem, Letter to the Editor, Supreme Court Makes Big Blunder, MilwaUKeE J. SenTinel, Mar. 19, 1996, at 9; Debra J. Saunders, $A$ Convoluted Court Ruling: Is Fairness Totally Disconnected from the Law?, ATLANTA J. \& CONST., Mar. 13, 1996, at A18; Debra Saunders, High Court Takes Low Road on Forfeiture, DET. FrEE PRESS, Mar. 13, 1996, at 9A; Savage, supra note 21, at 47; Michele Stevens, Take It From Him: Seizure Laws a Bad Deal, CHI. SUN-TIMES, Mar. 25, 1996, at 29 ("Tina Bennis thought common sense would prevail .... She was wrong."); Carle Gray Sullivan, Innocent Punished, BANGOR DAILY NewS, Mar. 23, 1996, available in LEXIS, Nexis Library, Arcnws File ("[S]imple equity/justice would dictate that the court [sic] should have refrained from punishing the innocent victim, Tina Bennis"); George E. Ward, Letter to the Editor, Checkout Time for Balancing the Budget, N.Y. TIMES, Mar. 13, 1996, at A18; George Will, High Court Deals a Setback to Property Rights, CHI. SUN-Times, Mar. 10, 1996, at 40 ("Tina Bennis ... found out the hard way: that our government only gives lip service to the rights of innocent victims."). But see It's a Legislative Job, PROVIDENCE J.-BULL., Mar. 15, 1996, at B6 (arguing that the Court in Bennis properly applied its precedent and that protection for "innocent owners" should be supplied by legislation, rather than court decisions).

258. See, e.g., Boudreaux \& Pritchard, supra note 11, at 593; Dery, supra note 104, at 359; Luna, supra note 100, at 409; Sandra Guerra, Family Values?: The Family As an Innocent Victim of Civil Drug Asset Forfeiture, 81 CORNELl L. REV. 343, 366-68 (1996). But see Deborah Jones Merritt, Forfeiture and Real Feminism, LEGAL TIMES, July 29, 1996, at S35; Seamon, supra note 102, at 389; Ward, supra note 248.

259. James J. Kilpatrick, From Piracy to Prostitution in the Courts, Buff. NEWS, Mar. 18, 1996 , at 3B.

260. Levendosky, supra note 257, at 15A.

261. His Crime, Her Car, WASH. Post, Mar. 9, 1996, at A23; Forfeiting Fairness, N.Y. Times, Mar. 8, 1996, at A30.

262. Stuart Taylor, Jr., A Car Is Not a Pirate Ship, Legal Times, Mar. 11, 1996, at 21; see also William E. Hellerstein, It Was a Very Good Year-For the Government: The Supreme Court's Major Criminal Rulings of the 1995-1996 Term, 13 TOURO L. REv. 395, 400 (1997) ("The most startling aspect of Bennis is that it was Justice Ginsburg's vote that sank Mrs. Bennis."); Forfeiting Fairness, supra note 261, at A30 ("[F]or reasons that are not clear in her skimpy concurring opinion, Justice Ginsburg ended up voting with the majority to uphold the forfeiture...."). 
an angry reaction from Stefan B. Herpel, the lawyer who represented Tina Bennis: "I think it's an outrageous decision, and I'm shocked and mystified by Justice Ginsburg."

Nevertheless, the history of proceedings against inanimate objects and animals may shed some light on both the Court's opinion and Justice Ginsburg's concurrence. As in those proceedings, John Bennis's 1977 Pontiac can be seen as a symbol of the breakdown of the community's moral order. Thus, perhaps it is not so surprising that the authorities might wish to remove the object itself in addition to sanctioning the guilty individual, or that forfeiture law might permit such a symbolic "banishment."

Indeed, the Bennis case arose from a Detroit anti-prostitution campaign called "Operation Save Our Neighborhood," which was created specifically in response to a demand by residents of north central Detroit for relief from the blighting effects of vice. ${ }^{264}$ At trial, the judge referred to testimony from neighborhood residents attesting to the scourge of prostitution in the area. ${ }^{265}$ For example, the judge described one resident who "has had to ... put up with the acts and frustrations of those engaging in some forms of [prostitution] activity in front of her home" at all times of the day and night, 365 days a year. ${ }^{266}$ According to the judge, "[she] cannot even walk along Eight Mile Road now; ... even when she wants to go for a little walk in the morning, she has to have her husband trailing behind her...."267 Another witness complained that his young son had seen acts of prostitution in cars parked near the very corner John Bennis chose. ${ }^{268}$

In such a blighted neighborhood, the cars themselves, driven by various men cruising the streets soliciting prostitutes, are one of the most visible symbols of the breakdown of order ${ }^{269}$ Indeed, according to the Wayne County prosecutor, "[o]ver sixty percent of the 'johns'

263. Savage, supra note 21 , at 48.

264. See Ward, supra note 248 , at 113.

265. See Transcript of Bench Ruling of Trial Court at 181-86, reprinted in J.A. at 15-19, Bennis v. Michigan, 516 U.S. 442 (1996) (No. 94-8729).

266. Id. at 184 , reprinted in J.A. at 18.

267. Id.

268. See Michigan v. Bennis, 527 N.W.2d 483, 491 (Mich. 1994).

269. Similarly, other cities have attempted to crack down on so-called "quality of life" offenses in part because of the symbolic value of ridding the community of such activities. See, e.g., Inside Politics (CNN television broadcast, Jan. 3, 1997) ("[New York City] Mayor [Rudolph] Giuliani tried a new approach to crime, ... a crackdown on so-called 'quality of life crimes' like graffiti and vagrancy to convince New Yorkers things had changed and the city was in control."); see also Dan M. Kahan, Social Influence, Social Meaning, and Deterrence, 83 VA. L. REV. 349, 351 (1997) ("Cracking down on aggressive panhandling, prostitution, open gang activity and other visible signs of disorder may be justifiable ... since disorderly behavior and the law's response to it are cues about the community's attitude toward more serious forms of criminal wrongdoing."). 
and other customers of vice markets operating in Detroit are nonresidents, and over ninety percent are non-residents of the particular neighborhood suffering the unpleasantness." ${ }^{270}$ As the Michigan Supreme Court held, "[w]here testimony surrounding proof of an incident of prostitution unequivocally establishes that the neighborhood has a reputation for prostitution, the property contributing to the continuance of the nuisance may be abated pursuant to the statute. To hold otherwise ... would permit the continuing blight of neighborhoods."271

For a community that has witnessed the collapse of its order, the cars themselves might be seen as symbolically guilty. Accordingly, the Save Our Neighborhood initiative attempted to restore equilibrium to the neighborhood in part by seizing the "tainted" automobiles and "banishing" them through forfeiture. Although the forfeitures also undoubtedly have a deterrent effect, it is important to note that, in this case at least, John Bennis was prosecuted for indecency, and the legislature could easily have imposed an additional fine or otherwise increased the punishment for such a crime. However, additional punishment aimed at the human transgressor would not have the same symbolic value as the act of seizing the car itself. Moreover, it is difficult to see what deterrent effect the seizure could have had on Tina Bennis, who admittedly was powerless to prevent her husband from using their jointly owned car. . $^{272}$

Thus, while both the majority opinion and Justice Ginsburg's concurrence speak of "deterrence," these references seem to be focused not so much on deterring specific individuals, but on deterring criminal activity in the larger sense by ridding the community of the instrumentality and symbol of vice. Chief Justice Rehnquist's opinion for the Court concludes that "[t]he Bennis automobile ... facilitated and was used in criminal activity," and observes that the activity in question "contributes to neighborhood deterioration and unsafe streets."273 And Justice Ginsburg's concurrence, so surprising to Court observers, explicitly rejected the dissent's contention that the government had "embarked on an experiment to punish innocent third parties."274 Instead, she stated

270. Ward, supra note 248 , at 111 n.22; see also Bennis, 527 N.W.2d at 491 ("Vehicles that enter the neighborhood in order to solicit acts of prostitution are being used for the continuance of this nuisance.").

271. Bennis, 527 N.W.2d at 492 .

272. As Justice Ginsburg asked at oral argument, "What was [Tina Bennis] supposed to do?" Tr. of Oral Argument 59, Bennis v. Michigan, 516 U.S. 442 (1996) (No. 94-8729).

273. Bennis v. Michigan, 516 U.S. 442, 453 (1996).

274. Id. at 458 (Ginsburg, J., concurring). 
simply that "Michigan has decided to deter Johns from using cars they own (or co-own) to contribute to neighborhood blight, and that abatement endeavor hardly warrants this Court's disapprobation."275 Such statements may seem manifestly unfair when viewed from the perspective of Tina Bennis's moral culpability. But when considered in light of the centuries-old tradition of banishing objects and animals to preserve the community's order, these conclusions may be more intelligible.

Similarly, many commentators criticized United States v. Ursery because they saw the civil forfeitures at issue as a second punishment heaped upon the owners. ${ }^{276}$ But again, if one views this decision in light of forfeiture history, the result may not be as surprising. After all, actions against the object or animal have always been viewed as separate from the prosecution of a culpable individual.

Moreover, as we can see from Bennis itself, the seizure of an object may well serve separate societal values from the punishment of the individual. For example, in 1996 a homeless man living in an impoverished neighborhood in West Palm Beach, Florida, burned down an abandoned "crack house" in what he described as an effort to save a blighted community. ${ }^{27}$ Significantly, the man, Samuel Mohammed, did not direct his wrath at the individuals who had perpetrated drug deals at the crack house. In fact, he stated that he did not bear any malice towards the individual dealers, users, and prostitutes in the neighborhood. ${ }^{278}$ Rather, he was concerned with rescuing a community "on the verge of self-destruction." 279 Thus, it is perhaps not surprising that Mohammed moved against the house itself, the symbol of a neighborhood that had been laid waste by gang warfare, violence, and poverty. ${ }^{280}$ And for that action, many recognized Mohammed as a hero; although he was charged with arson, he was ultimately acquitted by a jury. ${ }^{281}$

The Ursery Court appeared to recognize that forfeiture serves a societal value wholly separate from the punishment of a culpable individual. The majority opinion refers to in rem forfeitures as "remedial" actions brought by the State and distinguishes these

275. Id.

276. See, e.g., Rachel L. Brand, Civil Forfeiture as Jeopardy, 20 HARV. J. L. \& PUB. POL'Y 292 (1996).

277. See Kate Santich, Cleansed By Fire, The ORLAndo SEnTINEL, Nov. 3, 1996, at 6.

278. See Rivera Live (CNBC television broadcast, Aug. 7, 1996), transcript available in LEXIS, Nexis Library, Arcnws File, at 7.

279. Tom Knott, Florida City's Drug-War Hero Got a Raw Deal, WASH. Times, Aug. 1, 1996 , at C2.

280. See Santich, supra note 277 , at 6 .

281. See id. 
actions from punitive in personam penalties. ${ }^{282}$ The distinction is significant, because while a punitive penalty, by definition, focuses on punishment of an individual transgressor, a remedial action is brought against the object not as punishment, but as remedy for the harm suffered by the community as a whole.

This conception echoes the deodand tradition and its use of forfeiture as a means of preserving "the King's peace," rather than either punishing the owner or offering redress to a private party. Indeed, because deodands were considered a public remedial action that made the community whole after a wrongful death, it is not surprising that the English Parliament established a private wrongful death action at the same time that it abolished deodands. ${ }^{283}$ The forfeiture action had previously been deemed to supersede the system of private retributive justice because the party to be made whole was the community. ${ }^{284}$

Thus, Ursery, despite its absence of any explanatory rationale, can be understood to endorse the notion that forfeiture is a remedial action against an object to make the community whole rather than a punishment directed at an individual. Like the javelin that accidentally kills a boy, or the mill wheel that grinds a person to death, the object may become a tainted symbol of the wrongdoing, and the community may seek forfeiture to remedy the breach of the social norm and restore the society's equilibrium.

\section{CONCLUSION}

It is always possible, of course, to jettison history. Numerous legal practices with long historical pedigrees have fallen into disfavor because they no longer accord with contemporary notions of justice. The prosecution of legal actions against inanimate objects may be one such practice that has outlived its rationale. As stated at the outset, this Article takes no normative position on this question or on the wisdom or efficacy of modern forfeiture law generally.

However, it will not do for those who support the status quo simply to invoke the long tradition of the deodand as if history alone could justify contemporary legal doctrine. Conversely, critics of

282. See United States v. Ursery, 518 U.S. 267, 278 (1996); see also United States v. Bajakajian, 118 S. Ct. 2028, 2035 (1998) ("Traditional in rem forfeitures were... not considered punishment against the individual for an offense.").

283. See Finkelstein, supra note 99, at 170-71 ("[T]he abolition of the deodands went hand in hand with the passage of the first 'Act for Compensating Families of Persons Killed by Accidents' ... which took effect only a few days later ....").

284. See LEVY, supra note 3, at 18 ("[F]orfeiture to the crown of the offender's property rendered wholly futile any civil action for damages. ... In short, death, by converting a private wrong into a public one redressable by forfeiture, had the effect of barring civil redress for the tort, that is, the wrong that caused the death."). 
forfeiture law cannot simply dismiss this history as the irrational product of a primitive mind. As one commentator has noted, the trial of an object or animal "was not a game. It was undertaken for the good of society, and if properly conducted it was intended to bring social benefits to the community-benefits, that is, to human beings." ${ }^{\text {"285 }}$ Thus, both sides must acknowledge and attempt to understand the historical practice in its social context.

We can never know for certain why communities conducted legal actions against inanimate objects and animals. However, we can attempt to understand the roles such trials may have fulfilled and the narratives of justice those trials may have constructed. Indeed, this Article has argued that modern forfeiture law may fulfill similar roles and construct similar narratives. By analyzing the history of these seemingly irrational proceedings, we may gain a more nuanced understanding of current doctrine.

Moreover, once we take seriously the idea that forfeiture actions exist as much to heal the community as to punish the owner, we are able to identify various ramifications and avenues for further study. For example, psychological and sociological research might reveal whether the removal of a symbol of neighborhood blight (for example, a car that is recognized in a community as a drug courier vehicle) actually brings therapeutic benefits over and above the arrest of the human perpetrators. If so, then discussion of forfeiture policy could be informed by current scholarship regarding the use of "social norms" 286 to enforce societal order through such practices as shaming rituals. ${ }^{28}$ Under this view, we might be concerned that modern forfeiture practice does not always seem calculated to achieve a symbolic cleansing or a community catharsis. As we can

285. Humphrey, supra note 13 , at $\mathrm{xx}$.

286. See, e.g., Kahan, supra note 269, at 362 ("Against the background of [social] norms, actions become invested with meaning; they signify to others what a person (or community) believes and cares about."); Lessig, supra note 109, at 956 (arguing that social meanings "not only constitute, or guide, or constrain; they are also tools-means to a chosen end, whether an individually or collectively chosen end. They are a resource-a semiotic resource-that society provides to all if it provides to any."); Sunstein, supra note 109, at 911 ("We should try to see when social norms, social roles, and social meanings are obstacles to human well-being, and whether something might be done to change them, even if people are making 'choices,' even if there is neither force nor fraud, and whether or not there is "harm to others." ).

287. See Dan M. Kahan, What Do Alternative Sanctions Mean?, 63 U. CHI. L. REV. 591, $630-52$ (1996) (discussing the "rediscovery of shame" as a means to enrich "our punitive vocabulary"); see also Kahan, supra note 269, at 384 ("Shaming penalties-from bumper stickers for drunk drivers, to publicity for toxic waste dumpers, to signs or distinctive clothing for sex offenders-are on the rise in American law. Like imprisonment, these punishments convey condemnation in dramatic and unequivocal terms. They can thus be expected to 'inspire the public with sentiments of aversion' toward criminality through their effect on the forces of social influence." (footnotes omitted) (quoting JEREMY BENTHAM, AN INTRODUCTION TO THE PRINCIPLES OF MORALS AND LEGISLATION (J.H. Burns \& H.L.A. Hart eds., Athlone Press 1970) (1780))). 
see from the large number of people who turned out to watch as the contents of O.J. Simpson's home were carted away, ${ }^{288}$ there may be a perceived need for the community actually to participate more actively in the forfeiture event. Therefore, rather than permitting the State to sell the Bennis's car at auction (where, theoretically, a new person could purchase it and begin cruising the same neighborhood for prostitutes), perhaps the car should have been given to neighborhood residents for a ritual destruction, as with the burning of the abandoned crack house. ${ }^{289}$ Along the same lines, forfeiture law might be changed to apply only in those instances when the seizure of the object truly has symbolic or therapeutic value. Or, in contrast, we may reject the basic premise that the perceived needs of the community should be allowed to trump individual civil liberties. ${ }^{290}$ But these questions cannot be resolved without first taking seriously the notion that, at least in some situations, forfeiture can have an independent community value and is not simply an irrational and unjust practice built on a devious "fiction."

Finally, this study fits within a broader project whereby anthropologists and legal scholars have come to realize that law is in part concerned with the construction of narratives and social meanings that influence the way a community perceives reality. Thus, for every legal question, we must study the language being used to analyze the question, the symbolic content of the proceedings at issue, and the meaning being created. Such inquiry permits us to understand the social role that law fulfills for a community beyond its traditional role in dispute resolution. In the end we must realize that it is not only so-called "primitive" societies that create rituals to make sense of the world. We have legal rituals as well, and the forfeiture of an automobile or a house is not simply a deterrent legal action; it is a symbolic event. Only by recognizing the symbolic content of our own rituals of justice can we begin to decide which legal rules and procedures are truly best.

288. See Rick Orlov, Deputies Seize Items From Home of Simpson, SACRAMENTO BEE, Mar. 29, 1997, at A1 ("The arrival of the moving vans and deputies triggered a surge of reporters, helicopters - and sightseers-to the Brentwood community that was beginning to shake the spotlight.").

289. This practice would also remove the objection that forfeiture laws only exist to swell the government's coffers. See supra note 16 and accompanying text.

290. Such a discussion would implicate the more general debate between communitarianism and liberalism as to the proper balancing of community and individual interests. See generally LIBERALISM AND ITS CRITICS (Michael J. Sandel ed., 1984). 
